\title{
87. DATA REPORT: GEOCHEMISTRY AND MINERALOGY OF ASH LAYERS FROM LEGS 127 AND 128 IN THE JAPAN SEA ${ }^{1}$
}

\author{
André Pouclet, ${ }^{2}$ Kantaro Fujioka, ${ }^{3}$ Toshio Furuta, ${ }^{3}$ and Shigenori Ogihara ${ }^{4}$
}

\begin{abstract}
Deep-sea ash records from Legs 127 and 128 in the Sea of Japan provide reliable data about the nature and composition of explosive volcanic activity of the surrounding area since the middle Miocene. Special attention is given to glass alteration and a determination of initial magmatic compositions. Barium accumulations are responsible for massive crystallization of barite and harmotome in some altered ash layers.

The glasses are assigned to four compositional magmatic groups that correspond to various medium- and high-K andesite suites and to alkaline suites. Analyses of trace elements in selected ash layers distinguish two subgroups in the medium-K andesite suites (unenriched and moderately enriched in incompatible elements), one subgroup that corresponds to a K-andesite suite, and two alkaline subgroups of trachytic and phonolitic composition. Some Miocene ash layers exhibit compositions intermediate between the alkaline and the calc-alkaline suites. Compositions of coexisting minerals correlate with magmatic signatures: OPX and $\mathrm{Al}$ - and $\mathrm{Ti}$-poor $\mathrm{CPX}$ occur in the calc-alkaline ash layers, and $\mathrm{Al}-, \mathrm{Ti}-$, and $\mathrm{Na}$-rich $\mathrm{CPX}, \mathrm{K}$-rich plagioclases, and $\mathrm{Ti}$-rich biotites occur in the alkaline ash layers.
\end{abstract}

\section{INTRODUCTION}

Volcaniclastic material was recovered in lower Miocene to Quaternary sediments of the Japan Sea during Legs 127 and 128 (Fig. 1). Four sites were drilled during Leg 127, two to the east of the Japan Basin (Sites 795 and 796) and two within the Yamato Basin on its northeastern and western margins (Sites 794 and 797) (Tamaki, Pisciotto, Allan, et al., 1990). Two sites were drilled during Leg 128 at the Oki Ridge (Site 798) and at the Kita-Yamato Trough (Site 799). Moreover, Site 794 was revisited to drill deeper in the basement (Ingle, Suyehiro, von Breymann, et al., 1990). Recovery was excellent in Quaternary and Pliocene strata, less excellent, but satisfactory, in Miocene strata. The wide geographic spread of the sites provides an accurate record of the explosive volcanic activity of the Japan Sea region during middle Miocene to Quaternary time, with deposition of ash from the Japanese volcanic arc, from volcanic islands in the Japan Sea, and from the Korean volcanoes.

\section{VOLCANICLASTIC MATERIAL AT LEGS 127 AND 128}

The volcaniclastic material consists mainly of discrete ash layers $(0.1-20 \mathrm{~cm}$ thick) and dispersed glass shards of fallout deposition in all of the sedimentary sequences. The thickest deposits were recovered in Miocene strata, including a $27-\mathrm{m}$-thick pumice flow tuff at Site 799 and ash-fall and gravity-flow tuffs at Sites 794, 795, 796, and 797. Hyaloclastite tuffs were recovered at Sites 794 and 795, near the basaltic lavas of the basement.

Lithological and petrographical aspects of ash layers are described in a parallel note on tephrochronology (Pouclet and Scott, this volume). Detailed investigations at Sites 798 and 799 provide the most accurate frequency of the volcanic activity. A total of nine volcanic

\footnotetext{
'Tamaki, K., Suyehiro, K., Allan, J., McWilliams, M., et al., 1992. Proc. ODP, Sci. Results, 127/128, Pt. 2: College Station, TX (Ocean Drilling Program).

${ }^{2}$ Géotectonique et Pétrologie, Faculté des Sciences, Université, BP 6759, 45067 Orléans Cedex 2, France.

${ }^{3}$ Ocean Research Institute, University of Tokyo, 1-15-1 Minamidai, Nakano-Ku, Tokyo 164, Japan.

${ }^{4}$ Geological Institute, University of Tokyo, Hongo, Bunkyo-Ku, Tokyo 113, Japan.
}

pulses are distinguished and numbered from youngest to oldest: V1, V2, and V3 in the Quaternary, V4 and V5 in the Pliocene, V6 in the late Miocene, V7 and V8 in the late middle Miocene, and V9 in the middle Miocene. The distinction of volcanic pulses is based on quiescence of explosive volcanic activity (no ash deposits), and on sharp variations of activities (expressed by number and thickness of ash layers). Similar volcanic phases can be recognized at Sites 794, 795,796 , and 797. Table 1 indicates the number of sampled ash layers per volcanic phases at each site. Information about the distribution of ash layers has been drawn from Legs 127 and 128 Initial Reports volumes (Tamaki, Pisciotto, Allan, et al., 1990; Ingle, Suyehiro, von Breymann, et al., 1990).

Samples selected for petrographic and geochemical studies are shown on the stratigraphic summary columns for the western (Sites 799, 797, and 798) and northeastern (Sites 794, 796, and 795) parts of the Japan Sea (Fig. 2). Table 2 (back-pocket microfiche) presents the list of samples with their location and significant petrographical, chemical, and mineralogical features. Samples from Sites 799 and 798 have been numbered according to the Initial Reports volume's exhaustive list of ash layers (Ingle, Suyehiro, von Breymann, et al., 1990).

\section{Site 799 (Kita-Yamato Trough)}

Holes were drilled in the southwestern middle part of the KitaYamato Trough. The deepest hole ended in lower middle Miocene terrigeneous sediments $1084 \mathrm{~m}$ below seafloor (mbsf), about $115 \mathrm{~m}$ above the acoustic basement. The nine volcanic pulses are well defined and were dated by using paleomagnetic polarity transitions and fossil data. The oldest volcanic event, V9, equated with the prominent 27 -m-thick pumice flow tuff, has been dated about 12.5 Ma. It clearly indicates a major volcanic event linked to initial subsidence of the trough (Pouclet and Scott, this volume). A large selection of 90 samples of volcaniclastic material has been analyzed, along with three additional samples of sands from the hole's bottom, to determine their magmatic mineral content.

\section{Site 797 (Western Yamato Basin)}

Holes were drilled to the west of the Yamato Basin in Quaternary to middle or upper lower Miocene sediments. Drilling entered igneous basement from $554 \mathrm{mbsf}$ to the hole's end ( $900.1 \mathrm{mbsf}$ ). The basement 


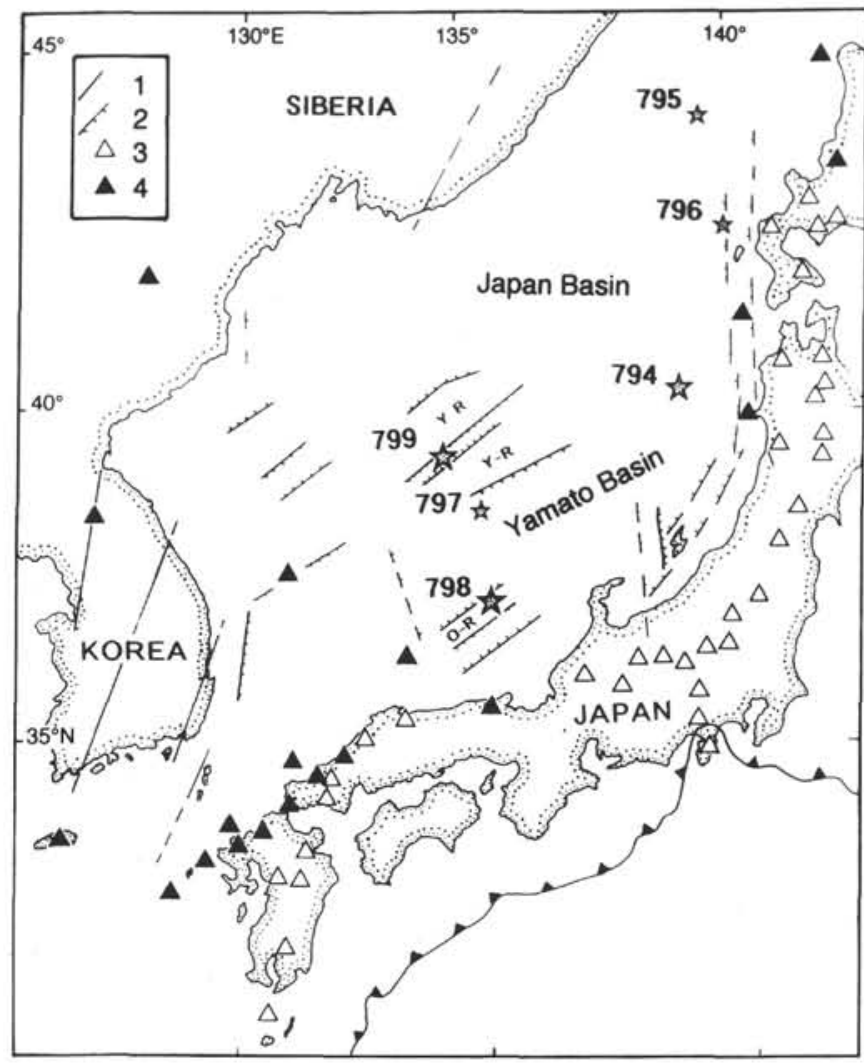

Figure 1. Geographic and structural setting of Leg 127 and 128 sites. $1=$ strike-slip faults; 2 = normal faults; 3 = calc-alkaline volcanoes; 4 = alkaline volcanoes; O-R = Oki Ridge; Y-R= Yamato Bank.

consists of basaltic lava flows and sills dated from 17 to $19 \mathrm{Ma}$ (Kaneoka et al., this volume). A maximum ash-layer frequency was noticed in Quaternary and Pliocene sediments that corresponded to V1 through V5 volcanic pulses. Another maximum is located in late middle and late Miocene age strata, with fallout ash deposits related to the V8 and V9 active phases. Nineteen samples were analyzed.

\section{Site 798 (Oki Ridge)}

This site was intended to record a reference stratigraphic sequence in sediments deposited above the calcium carbonate compensation depth on top of Oki Ridge. Drilling was halted at $517.9 \mathrm{mbsf}$ in late Pliocene age strata because of increases in hydrocarbon gases. Because of quiet sedimentation, a complete and high-resolution record of ash layers was obtained that corresponded to the V1 through V5 volcanic phases. A total of 55 ash samples were studied.

\section{Site 794 (Northeastern Yamato Basin)}

The objective of this site was the recovery of basement rocks. Stacked basalt sills and rare interbedded sediments were penetrated below the sediment pile at 542.4 mbsf. The deepest hole ended at $733.5 \mathrm{mbsf}$ in acoustic basement. Two superposed volcanic complexes can be distinguished and were dated between 20 and $18 \mathrm{Ma}$ (Pouclet and Bellon, this volume; Kaneoka et al., this volume). The frequency of ash layers shows four peaks in the Quaternary to upper Miocene sediments that correspond to the V1 through V6 pulses. Another maximun was observed in middle Miocene sediments having thick tuff beds, which may be related to the V8 and V9 pulses. In addition, a tuffaceous silty claystone was recovered inbetween igneous units. It includes blocky shards of hyaloclastites and its possible age might be $19 \mathrm{Ma}$ or older. We analyzed 25 samples from this site.

\section{Site 796 (Eastern Japan Basin)}

This site is located on Okushiri Ridge in the eastern margin of the Japan Basin. Drilling ended at 464.9 mbsf in middle Miocene sediments, about $110 \mathrm{~m}$ above basement, because of unstable hole conditions. Abundant volcanic detritus and discrete ash layers were recovered in Quaternary to Pliocene sediments that correspond to V1 through V 5 volcanic pulses. Some thick tuff beds are present in upper Miocene (V6-V7 pulses) and in middle Miocene sediments (V8-V9 pulses). Only 19 ash samples have been selected from the PlioceneQuaternary strata, the Miocene tuff glasses having been totally converted to smectites and zeolites.

\section{Site 795 (Northeastern Japan Basin)}

The objective of study at this site was to determine the age and the nature of the basement. Basaltic flows were penetrated from 683.5 to $762.2 \mathrm{mbsf}$, the hole bottom. They have been dated from 24 to $17 \mathrm{Ma}$ (Kaneoka et al., this volume). The distribution of volcaniclastics in the sediment pile shows distinct peaks of activity in the Quaternary and the Pliocene (V1-V5), in the late Miocene (V6-V7), in the late middle Miocene (V8 and V9), and in the middle Miocene above the basalt flows. The latter material is hyaloclastite tuffs related to subaqueous outpouring of basalt flows. We selected 14 samples in the Pliocene and Quaternary strata for analysis. The Miocene ashes were much too altered for analysis.

\section{GEOCHEMISTRY OF VOLCANIC GLASSES}

\section{Analytical Method}

\section{Major Elements}

The glass fragments and minerals were analyzed using an electron-probe microanalyzer (EPMA). Samples from Sites 794, 797, 798, and 799 were investigated at the University of Orléans (France), and samples from Sites 795 and 796 at the Ocean Research Institute of Tokyo (Japan). Some of these latter samples were duplicated at Orléans for technical corrections to obtain an internally consistent analytical population. Analytical shifting during determination of major elements from the EPMA method applied to glass material has been corrected by systematic adjustment with reference to high-quality synthetic glasses of known composition.

In each sample, 10 to 30 glass fragments were analyzed, depending on the homogeneity of the glass population. We selected optically unaltered fragments. The total amount of oxide components ranges from $91 \%$ to $98 \%$. In the absence of apparent alteration, the deficit comes from the initial volatile content and from seawater hydration. Hydration occurs rapidly to a saturation point during the sedimentation process (Pouclet et al., 1990). Beyond this point, secondary minerals develop in the glass (clay minerals, zeolites, tridymite or cristobalite, and alkaline feldspar). However, hydration of glasses can modify the chemical composition by leaching or concentration of elements (hydrolysis of the large ions: sodium, potassium, calcium, and magnesium, Pouclet et al., 1990), thus the analyses must be corrected for this possibility. This is done by considering the correlation coefficients among oxides and loss on ignition in a population of glasses having the same magmatic affinity, taking into account the differentiation effect. Final corrected data calculated to $100 \%$ are presented in Table 3 (back-pocket microfiche). $\mathrm{Fe}_{2} \mathrm{O}_{3}$ and $\mathrm{FeO}$ contents are needed for norm calculations. They have been estimated following Kilinc et al. (1983) and Whitney et al. (1988), given a ferric/ferrous ratio of 0.30 in acidic calc-alkaline glasses. 
Table 1. Number of analyzed samples per sites and per volcanic phases.

\begin{tabular}{|c|c|c|c|c|c|c|c|}
\hline $\begin{array}{c}\text { Estimated } \\
\text { age } \\
\text { (Ma) } \\
\end{array}$ & $\begin{array}{c}\text { Volcanic } \\
\text { phase }\end{array}$ & $\begin{array}{l}\text { Site } \\
799\end{array}$ & $\begin{array}{l}\text { Site } \\
797\end{array}$ & $\begin{array}{l}\text { Site } \\
798\end{array}$ & $\begin{array}{l}\text { Site } \\
794\end{array}$ & $\begin{array}{l}\text { Site } \\
796\end{array}$ & $\begin{array}{l}\text { Site } \\
795\end{array}$ \\
\hline \multirow{2}{*}{0.5} & V1 & 39 & \multirow{3}{*}{12} & 27 & \multirow{2}{*}{5} & \multirow{3}{*}{12} & \multirow{2}{*}{8} \\
\hline & v2 & 19 & & 15 & & & \\
\hline 1.4 & V3 & 3 & & 2 & 2 & & 2 \\
\hline \multirow{2}{*}{3.4} & V4 & 5 & \multirow{2}{*}{5} & 1 & \multirow{2}{*}{8} & \multirow{2}{*}{7} & 4 \\
\hline & V 5 & 6 & & 10 & & & \\
\hline 5 & V6 & 9 & \multicolumn{5}{|c|}{6} \\
\hline 6.7 & V7 & 5 & & & & & \\
\hline $10.5 ?$ & V 8 & 2 & \multirow{2}{*}{2} & & \multirow{3}{*}{3} & & \\
\hline $12.0 ?$ & V9 & 2 & & & & & \\
\hline $19 ?$ & & & & & & & \\
\hline Total (222): & & 90 & 19 & 55 & 25 & 19 & 14 \\
\hline
\end{tabular}

\section{Minor Elements}

A total 25 ash samples were selected from glass-rich and homogeneous ash layers (homogeneous in morphology, size range, and microprobe major-element composition) for trace element and rare earth element (REE) analysis by using an inductively coupled plasma spectrometer (ICP). Table 4 (back-pocket microfiche) presents the ICP data for major (wt\%) and trace (ppm) elements. Loss on ignition (LOI, $1000^{\circ} \mathrm{C}$ ) is the total volatile element content and includes $\mathrm{H}_{2} \mathrm{O}+$, $\mathrm{H}_{2} \mathrm{O}-, \mathrm{CO}_{2}$, etc. The LOI ranges from 3.80 to 10.10 , in agreement with the EPMA results, except for some highly altered samples. Compared to the EPMA analyses, the ICP analyses are poorer in silica and sometimes richer in alumina, lime, and alkalies, because of incomplete separation of feldspar.

\section{The Alteration Problem}

\section{Frequency of Ash Beds}

Alteration is a nagging question when analyzing ash material. Alteration mainly depends on pore-fluid composition and geothermal gradient; it may occur rapidly at shallow depths (150-200 mbsf). With increasing depth in the sediment pile, it becomes more and more difficult to analyze "fresh" (only hydrated) glass, precluding easy recognition of volcanic beds. Tephrochronology records show systematically fewer numbers of ash layers back into mid-Cenozoic time. Obviously, the number of ash layers has been underestimated in the oldest strata because of alteration of ash beds and poorer core recovery. This can be partly corrected by adding the logged ash layers from the formation microscanner (FMS) record, which allows one to recognize resistive ash beds, and from the NGT record, where thicker ash layers were identified by sharp increases in the $T h / U$ ratio. However, only thick tuff beds have been numbered in the Miocene cores. According to Keene (quoted in Kastner, 1979), the transformation of siliceous sediments (opal-A) to porcellanite (opal-CT) and chert (quartz) results in a volume reduction by a factor of 4 to 10 . Consequently, a 1-mm-thick ash layer becomes indiscernible, and the thickness and number of ash beds has been underestimated in deeper strata, compared with those in shallower strata. Thus, we cannot assume perfect representation and accuracy of ash sampling in Miocene strata.

\section{Secondary Mineralogy}

\section{Silica Diagenetic Evolution}

During Legs 127 and 128, alteration of ash layers was conventionally correlated with the opal-A/opal-CT/quartz diagenetic transitions, which are partly controlled by geothermal gradient. High heat-flow values are generally measured in the Sea of Japan, and temperature gradient ranges between $83^{\circ}$ and $178^{\circ} \mathrm{C} / \mathrm{km}$ in the holes (Tamaki, Pisciotto, Allan, et al., 1990; Ingle, Suyehiro, von Breymann, et al., 1990). Lower values characterize the Kita-Yamato and Oki Ridge Sites 798 and 799 and may be indicative of thin continental crust underneath. Medium values $\left(121^{\circ}-\right.$ $133^{\circ} \mathrm{C} / \mathrm{km}$ ) were measured at the basinal Sites 794, 975, and 797. An unusually high value $\left(178^{\circ} \mathrm{C} / \mathrm{km}\right)$ was recorded at the Okushiri Ridge Site 796 (heat source from fluid flow along faults?). Consequently, the opal-A/opal-CT boundary $\left(36^{\circ}-43^{\circ} \mathrm{C}\right)$ is located between 215 (Site 796) and 456 (Site 798) mbsf in the uppermost Miocene to lower Pliocene sediments. The opal-CT/quartz boundary $\left(46^{\circ}-53^{\circ} \mathrm{C}\right)$ is located between 310 (Site 796) and 585 (Site 799) mbsf in upper Miocene to upper middle Miocene sediments.

Above the opal-A/opal-CT transition, glass dissolution features are limited to scattered small pits (PI. 1). Smectite alteration becomes significant around 200 mbsf (it begins at 90 mbsf at Site 799 and at $175 \mathrm{mbsf}$ at Site 798). In the early Pliocene age strata, some ash beds have been highly affected by leaching of $\mathrm{K}_{2} \mathrm{O}$ from glasses and formation of smectites and sparse authigenic phillipsite. Glass alteration and attendant $\mathrm{Al}$-enrichment is responsible for the normative corundum in the norm calculation.

In the opal-CT zone, rare "fresh" (only hydrated) glasses can be analyzed, and their analytical deficits reach $8 \%$ to $10 \%$. Glass surfaces are strongly pitted (Pl. 1). Chemical alteration of glasses evolves in two ways, either to alkali loss or to alkali enrichment and increases in the $\mathrm{Al} / \mathrm{Si}$ ratio. Depending on the behavior of alkali, this may or may not lead to corundum normative composition. Mineralogical evolution seems to be controlled by the formation of celadonite in the glass rim and/or crystallization of zeolites, potassic feldspar (adularia), and silica, because of more or less confined-environment conditions (Honnorez, 1981).

Below the opal-CT/quartz transition, "fresh" glass is rare as lithification is complete. Because of high glass dissolution, feldspar and pyroxene laths have weathered out their glass matrix (PI. 1). Analytical deficits 


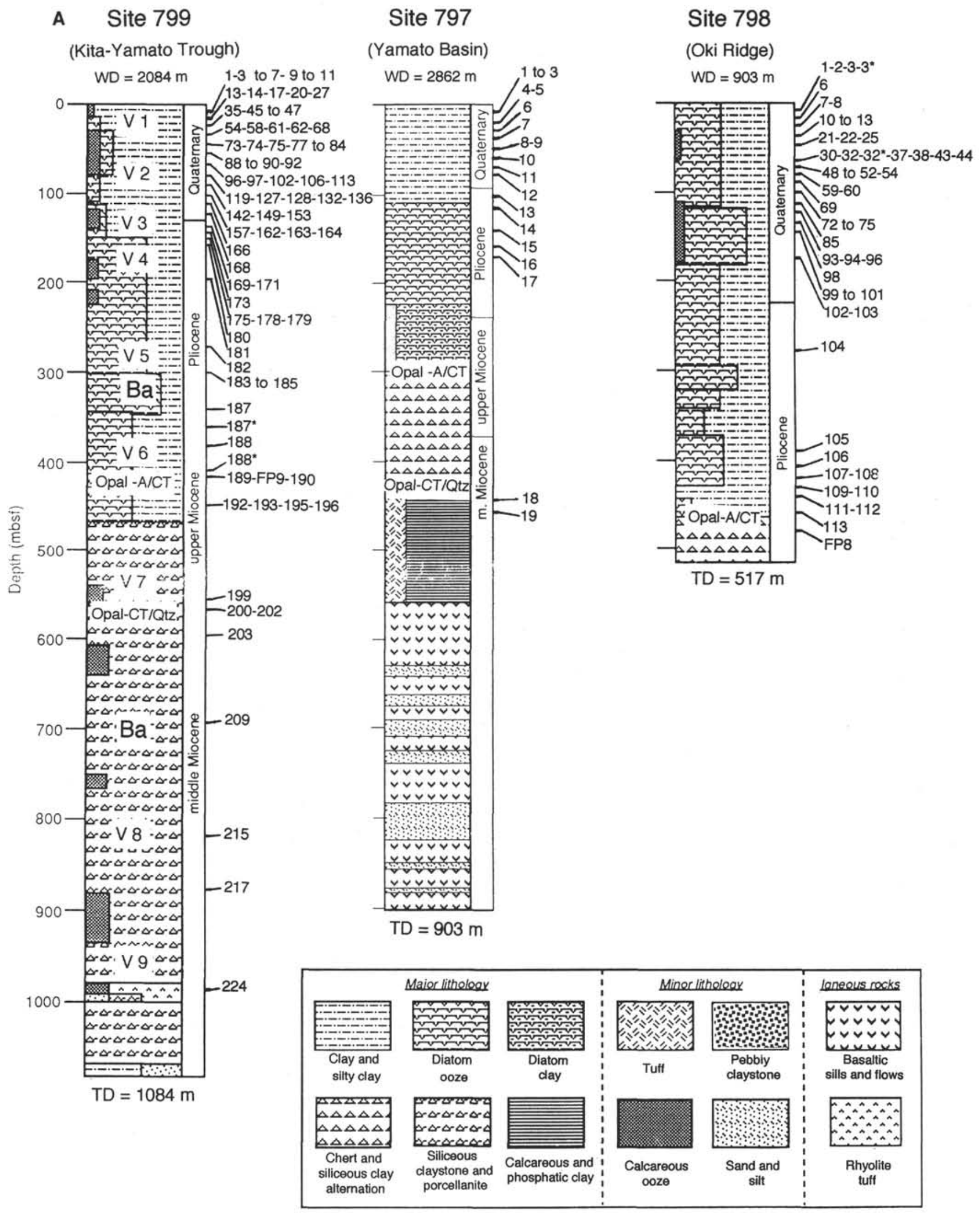

Figure 2. Stratigraphic summary columns and location of samples. A. Western part, Sites 799, 797, and 798. B. Northeastern part, Sites 794, 796, and 795. V1 through V $9=$ volcanic phases; $\mathrm{Ba}=$ barium anomalies; Opal-A/Opal-CT and Opal-CT/Quartz boundaries; WD $=$ water depth; TD $=$ total depth below seafloor. 


\section{B Site 794}

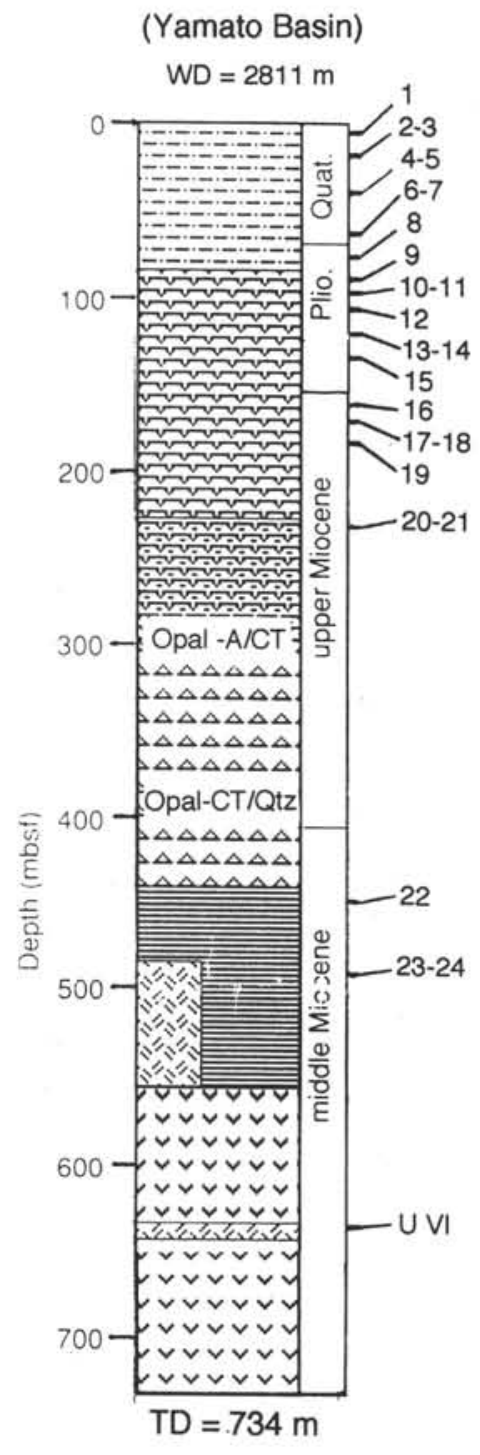

\section{Site 796}

(Okushiri Ridge)

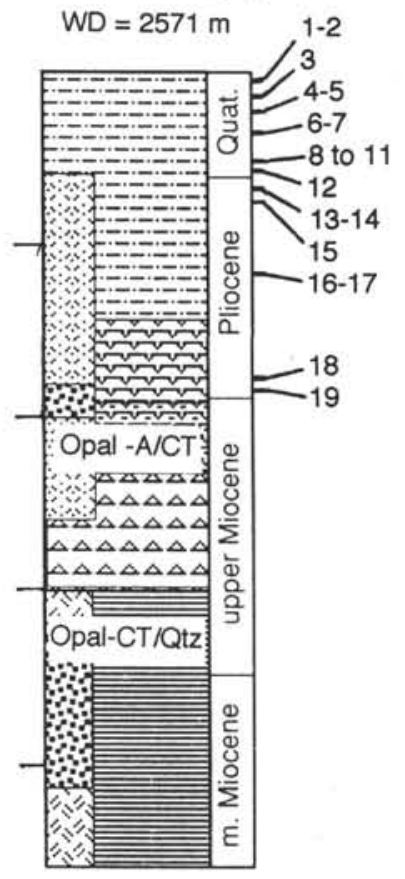

$\mathrm{TD}=465 \mathrm{~m}$
Site 795

(Japan Basin)

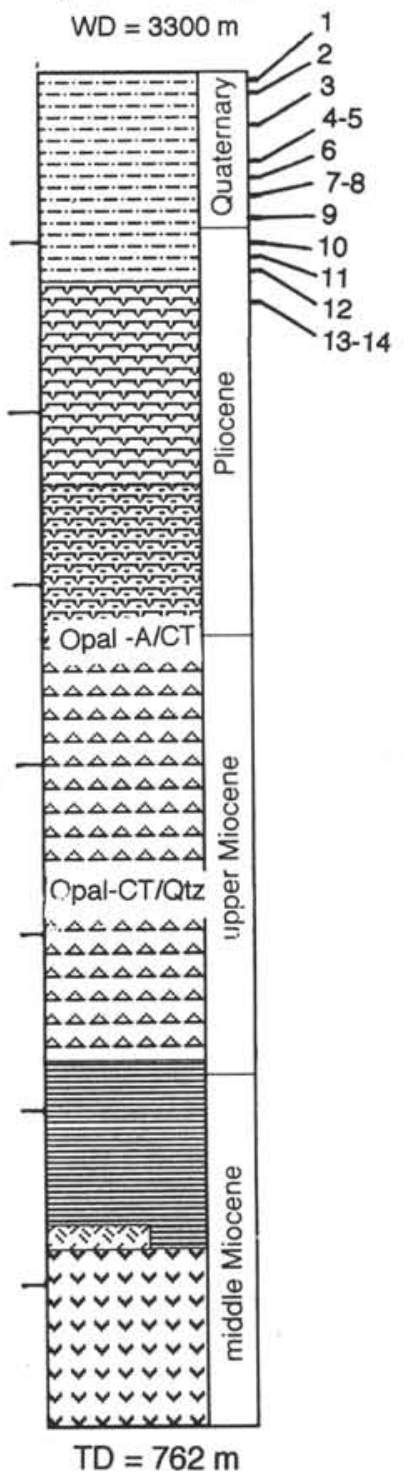

Figure 2 (continued).

exceed $10 \%$ and are indicative of a large development of smectite. Zeolites and potassic feldspars are common, as is platy quartz. Abundant authigenic crystals of orthoclase or adularia (Pl. 2) characterize the ash layers 9-200 to 9-209 (Samples 128-799B-15R-2, 81-83 cm, to $128-799 \mathrm{~B}-15 \mathrm{R}-4,95-96 \mathrm{~cm}$ ) just at the opal-CT/quartz boundary. Clinoptilolite is the most common zeolite below this boundary, especially in the pumice flow layer 9-224 (Sample 128-799B-21R-5, $47-51 \mathrm{~cm}$ ).

The original magmatic composition of altered glass can be approximated from the secondary mineralogy. In the deepest, totally altered, rhyolitic ash beds, smectites have been replaced by illite and silica. In the upper part of two subunits of the Miocene pumice flow tuff at Site 799, 10- to 40-cm-thick intervals of authigenic calcite have recrystallized, indicating strong leaching of $\mathrm{Ca}$ and probably $\mathrm{K}$ and $\mathrm{Na}$ dissolution in pore fluids. At Site 794, in the Miocene hyaloclastite layer, typical palagonitization of blocky glass fragments was observed and is indicative of a former basaltic composition (Pl. 3).
Fragments show an outer rim of residual sideromelane coated with a smectite rind. The inner rim consists of successive fibrous and gelpalagonite zones. Smectites and $\mathrm{Fe}$ - and Ti-hydroxides are concentrated in the core around a vesicle.

\section{Barium Anomalies}

Specific secondary mineralogy has been linked to barium anomalies. At Site 799, various barium enrichments in ash layers are responsible for barite precipitation and for replacement of volcanic glass by authigenic harmotome. A positive barium anomaly was detected between 180 and 287 mbsf in ash layers 9-179 and 9-182 (Samples 128-799A-20H-4, 84-86 cm, and 128-799A-32X-6, 102$104 \mathrm{~cm}$ ) with, 2649 and $2054 \mathrm{ppm} \mathrm{Ba}$, respectively (average Ba content in rhyolite tephra is $500-1000 \mathrm{ppm}$; Table 4). The first massive precipitation of barite was detected at $323 \mathrm{mbsf}$ at Section $128-799 \mathrm{~A}-36 \mathrm{X}-5,23-26 \mathrm{~cm}$, in a 2-cm-thick, light gray tan layer that 
was suspected to be altered ash. Analysis indicates an astonishing barium enrichment of $7.64 \mathrm{wt} \%$ (and $3089 \mathrm{ppm}$ of Sr) that consisted of tiny $(2-10 \mu \mathrm{m})$ barite crystals in a biogenic clay. Calculated barium sulfate content reaches as high as $13 \%$. No recognizably volcanic material was found. However, barium again has been concentrated in altered ash layers between 344 and $700 \mathrm{mbsf}$, as in the layer 9-187 (Sample 128-799A-38X-6, 77-79 cm) with $2023 \mathrm{ppm}$ Ba. In layer 9-199 (Sample 128-799B-14R-2, 32-34 cm, 60\% glass), barite aggregates have crystallized with pyrite framboids, and some pyrite has been included in barite crystals (Pl. 4, Fig. 3). Similar barium enrichments occur in ash layers 9-203 (Sample 128-799B-18R-4, 19-21 cm), 9-209 (Sample 128-799B-27R-5, 47-51 cm), 9-215 (Sample 128-799B-41R-1, 32-34 cm), and 9-217 (Sample 128-799B-46R-3, $148-150 \mathrm{~cm})$. A peculiar alteration of glass was observed in layer 9-209: glass shards have been totally replaced by authigenic assemblage of harmotome crystals $(2-6 \mu \mathrm{m})$, which grew into a highly dissolved silica framework (PI. 5; Table 5, back-pocket microfiche). This harmotome alteration is devoid of clay minerals, and the sample has a barium content of an astonishing $9.57 \mathrm{wt} \%$.

\section{Chemical Composition of Glasses}

\section{Chemical Nomenclature}

A total 206 glass samples were analyzed (Table 3). Most of the samples (80\%) are homogeneous and intermediate to acidic in composition. Some $(12 \%)$ are heterogeneous with mixed mafic or intermediate to acidic glasses. These compositional types correspond to the sedimentary types $\mathrm{H}$ (homogeneous) and $\mathrm{G}$ (graded) of Pouclet and Scott (this volume). Other samples ( $8 \%$ ) contain detritally mixed glasses of various magmatic compositions (calc-alkaline and alkaline, see below) and correspond to the sedimentary types $\mathrm{T}$ (heterogeneous) and TT (turbidite layer).

Examination of the major-element data in variation diagrams (see below) and from norm calculations permitted us to distinguish four chemical groups: (1) a calc-alkaline and moderately alkaline group, (2) a calc-alkaline and peralkaline group, (3) a calc-alkaline and high-K group, and (4) an alkaline group (Table 6, back-pocket microfiche).

Group 1. Compositions of glasses were assigned to various andesitic magma series. They account for $57 \%$ of the total number of analyses. Their petrochemical nomenclature uses the $\mathrm{SiO}_{2}$ content, as follows: $<56 \%=$ basaltic andesite (BA), $56 \%-63 \%=$ andesite $(\mathrm{AN})$, $63 \%-70 \%=$ dacite (DC), $70 \%-74 \%=$ rhyodacite $(\mathrm{RD})$, and $>74 \%=$ rhyolite (RH) (Peccerillo and Taylor, 1976, modified for the acidic glasses that are richer in silica than whole rocks). Rhyodacite and rhyolite compositions represent $94 \%$ of this group. Normative quartz ranges from 6 to 27 in dacites, from 17 to 36 in rhyodacites, and from 31 to 51 in rhyolites.

Group 2. Because of magmatic depletion of alumina, some alkalirich dacitic to rhyolitic glasses ( $6 \%$ of the total number of analyses) have a peralkaline composition (molar ratio of $\left(\mathrm{Na}_{2} \mathrm{O}+\mathrm{K}_{2} \mathrm{O}\right) / \mathrm{Al}_{2} \mathrm{O}_{3}$ exceeding 1). Consequently, normative acmite is calculated in peralkaline dacite (DCP), peralkaline rhyodacite (RDP), and peralkaline rhyolite (RHP). The nomenclature is the same as that for Group 1.

Group 3. Some K-rich calc-alkaline glasses (8\% of the analyses) have a shoshonitic affinity with high-alkali and high-alumina contents (Peccerillo and Taylor, 1976; Gill, 1981). The petrochemical distinction is based on the $\mathrm{SiO}_{2}$ content used for the andesitic series: $\angle 56 \%=$ shoshonite (SH), 56\%-63\% = banakite (BK), 63\%-70\% = latite (LA) or K-dacite (DCK), 70\%-74\% = K-rhyodacite (RDK) or quartztrachyte (TQ), and $>74 \%=\mathrm{K}$-rhyolite $(\mathrm{RHK})$. Except for the shoshonites (slightly undersaturated), compositions are moderately silica oversaturated. The peralkaline index is lower than 1 , because of the high $\mathrm{Al}_{2} \mathrm{O}_{3}$ contents.

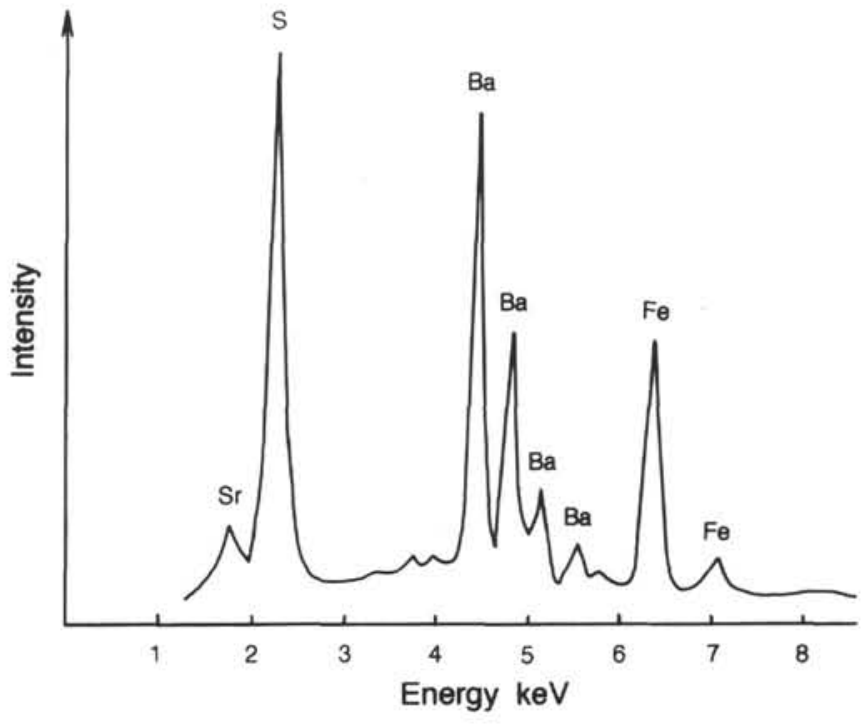

Figure 3. Energy dispersive spectra of barite and pyrite of Sample 9-199 (Sample 128-799B-14R-2, 32-34 cm; see PI. 4).

Group 4. Alkaline compositions represent $29 \%$ of the analyses. The nomenclature is based on the differentiation index (DI of Thornton and Tuttle, 1960), according to the limits of Pouclet (1980), and on the normative nepheline or quartz contents: DI $<35=$ basanite (BS), 35-50 = hawaiite (HW), 50-65 = mugearite (MG), 65-80 = benmoreite $(\mathrm{BN})$ or phonolite $(\mathrm{PH})$ if Ne norm $>5$, and trachy-phonolite (TP) if Ne norm is between 5 and $0, \mathrm{DI}>80=$ trachy-phonolite (TP) if Ne norm is between 5 and 0 , trachyte (TR) if quartz norm is between 0 and 5 , and quartz-trachyte (TQ) if quartz norm $>5$. The following proportions of alkaline acidic glasses were found: $31 \% \mathrm{PH}$, $16 \% \mathrm{TP}, 21 \% \mathrm{TR}$, and $32 \% \mathrm{TQ}$.

\section{Major Element Variation}

The analyses of major elements have been plotted on $\mathrm{SiO}_{2}$ vs. oxides variation diagrams, which show evidence for the four compositional groups (Fig. 4). The calc-alkaline Group 1 shows a compositional range in the medium- to the high-K andesite series (Gill, 1981).

Peralkaline dacites to rhyolites (DCP, RDP, RHP) of Group 2 have been depleted in $\mathrm{Al}_{2} \mathrm{O}_{3}$. This is not the case for the potassic and shoshonitic calc-alkaline Group 3.

The alkaline Group 4 exhibits a large range of composition, especially $\mathrm{Al}_{2} \mathrm{O}_{3}$ and $\mathrm{Na}_{2} \mathrm{O}$ in phonolites; this is caused by heterogeneity of glasses. Phonolitic and trachytic glasses are distinguished in the $\mathrm{SiO}_{2}$ vs. $\mathrm{K}_{2} \mathrm{O}$ diagram. Compared to the calc-alkaline glasses at the same $\mathrm{SiO}_{2}$ contents, the alkaline glasses have higher contents of $\mathrm{Al}_{2} \mathrm{O}_{3}$ and lower contents of $\mathrm{FeO}, \mathrm{MgO}$, and $\mathrm{CaO}$.

The magmatic groups show a geographic distribution in the three main areas. At Site 799 (Yamato Bank area), alkaline and peralkaline glasses are predominant. At Sites 797 and 798 (Yamato Basin), alkaline glasses are abundant, together with calc-alkaline andesitic products. At Sites 794, 796, and 795 (eastern Japan Basin), calc-alkaline glasses prevail; alkaline glasses seem to be rare, but some shoshonitic products are present.

\section{Magmatic Distinctions of Trace Elements}

Trace elements are powerful tools for discriminating magmatic series. The analyzed samples were selected to represent the main 
chemical types (Table 4). Inter-element correlations of incompatible elements clearly separate calc-alkaline and alkaline groups, the latter being highly enriched in $\mathrm{Th}, \mathrm{Nb}, \mathrm{Zr}$, Y, and REE (Figs. 5 and 6). Three subgroups can be distinguished in the calc-alkaline compositions. Subgroup A (Samples 8-2, 8-22, 8-50, 9-5, and 9-89) shows weak light rare earth element (LREE) enrichment and low incompatible element contents. Subgroup B (Samples 8-43, 8-75, 8-98, 9-166, 9-179, and 9-182) is slightly richer in the LREEs and incompatible elements, except for Zr. The rhyolites (Samples 8-104 and 8-106) may belong to this subgroup if they have suffered a loss of $\mathrm{Zr}$. These two subgroups correspond to rhyolites of distinct medium-K andesite series included in the magmatic Group 1. Subgroup C corresponds to rhyodacites (Samples 8-8, 8-59, and 9-68) richer in incompatible elements than the former rhyolites and related to a distinct and higher-K andesite series. Different patterns characterize rhyolite Sample 9-187, highly enriched in $\mathrm{Nb}$, Th, $\mathrm{Y}$, and $\mathrm{Yb}$, and possibly related to a tholeiite series. The pumice-flow rhyolite Sample 9-224 is moderately enriched in incompatible elements. The rhyodacite Sample 9-127 shows the same high field strength element (HFSE) and LREE enrichment as trachytes, but it is depleted in $\mathrm{Nb}$; these are features of shoshonitic series. One might expect more details about the different andesitic series of these subgroups by using all the trace elements. But first, the incompatibility of some elements, such as $\mathrm{Zr}$, in acidic compositions is not well constrained, and second, the seawater alteration may have affected some trace-element contents. Pearce and Cann (1973) assumed that the HFSEs are immobile during seawater alteration of basalts. For Saunders and Tarney (1984), Th was also apparently immobile. This may not be true in the case of acidic ash layers. We suspect a $\mathrm{Zr}$ mobility in the highly hydrated glasses (Samples 8-104 and 8-106). We discussed above the high mobility of Ba. Mobility of the large ion lithophile elements (LILEs) is probable.

Two subgroups can be distinguished in the alkaline composition group. Subgroup D gathers the trachytes (Samples 9-45, 9-83, and 9-96) and Subgroup E, the phonolites (Samples 8-48, 9-47, and 9-168), which are distinctly richer in LREEs and HFSEs.

\section{MINERALOGY}

Ash-sized mineral fragments are common in selected samples. These are either pyroclastic phenocrysts or xenocrysts, co-genetic with glass shards when they are coated by glass, or epiclastic detrital grains. We analyzed feldspars, pyroxenes, amphiboles, and biotites of magmatic origin (Table 7, back-pocket microfiche), rare pyroclastic or epiclastic oxides, and a few detrital epidotes. Locations of analyzed minerals are given in Table 2 .

\section{Feldspars}

In mafic to intermediate calc-alkaline ash layers (BA, AN, DC), abundant plagioclase fragments show a large compositional range of $\mathrm{An}_{81-29}$ with a low- to moderate-K content of $\mathrm{Or}_{0.6-4.3}$. In acidic ashes ( RD, RH), plagioclases are less abundant and more sodic, and also exhibit a large range of composition $\left(\mathrm{An}_{51-10}\right.$ and $\left.\mathrm{Or}_{0.8-14}\right)$ (Fig. 7, Field a). Alkali feldspars are more frequent in acidic layers (PI. 4). Their composition is either sodic $\left(\mathrm{Ab}_{99-65}\right)$, potassic $\left(\mathrm{Ab}_{35-3}\right)$, or intermediate $\left(\mathrm{Ab}_{65-35}\right)$. Sodic and potassic feldspars may coexist; exsolutions of albite were observed in sodic sanidine. Peralkaline and high-K dacitic and rhyolitic ashes contain similar feldspars, but some plagioclases can be more potassic.

In the alkaline trachyte and phonolite ash layers (PH, TP, TR, TQ), plagioclases are less calcic and more potassic $\left(\mathrm{An}_{58-19}\right.$ and $\left.\mathrm{Or}_{3-17}\right)$ (Fig. 7, Field b). Alkaline feldspars are sodic or potassic. They are very abundant in the trachyte glass layers. Moreover, glass coating on mineral pyroclasts is frequent.
The compositions of feldspars of the different magmatic groups are shown in Figure 7.

\section{Pyroxenes}

Pyroclasts of orthopyroxenes (OPXs) and clinopyroxenes (CPXs) characterize the calc-alkaline ash beds (Fig. 8). They are euhedral and green to light brown in color. OPXs are slightly more magnesian in mafic ashes $\left(\mathrm{Wo}_{2-4}, \mathrm{En}_{70-64}, \mathrm{Fs}_{28-32}\right)$ than in acidic ashes $\left(\mathrm{Wo}_{1-4}\right.$, $\left.\mathrm{En}_{66-48}, \mathrm{Fs}_{32-51}\right)$. CPXs are scarce in mafic beds. In acidic beds, they show little variation in composition $\left(\mathrm{Wo}_{45-40}, \mathrm{En}_{45-41}, \mathrm{Fs}_{10-16}\right)$ and low contents of $\mathrm{Al}_{2} \mathrm{O}_{3}(<4.5 \%)$ and $\mathrm{TiO}_{2}(<0.5 \%)$, a normal feature of subalkaline pyroxenes (Gill, 1981).

Green to brown pyroxene fragments were found in the alkaline ash beds. Only CPXs were present (Fig. 8). These consist of aluminaand titanium-rich $\left(\mathrm{Al}_{2} \mathrm{O}_{3} 4 \%-7 \%, \mathrm{TiO}_{2} 2 \%\right)$ diopside $\left(\mathrm{Wo}_{47-40}\right.$, $\left.\mathrm{En}_{42-39}, \mathrm{Fs}_{7-16}\right)$. In some trachyte ashes, altered dark brown fragments were determined to be former sodic diopside and aegirine $\left(\mathrm{Na}_{2} \mathrm{O}=2 \%-8 \%\right)$; these plot near the hedenbergite and clinoferrosilite compositions (Fig. 8).

\section{Amphiboles}

Dark green or brown amphibole crystals were analyzed only in calc-alkaline ash layers. They display various compositions, including hornblende, pargasitic hornblende, and tschermakitic hornblende (Leake, 1978). The ferromagnesian ratio ( $\mathrm{FeO}$ total $+\mathrm{MnO} / \mathrm{FeO}$ total $+\mathrm{MnO}+\mathrm{MgO})$ is lower in amphiboles from andesite and rhyodacite ashes $(0.25-0.30)$, relative to those from rhyolite ashes $(0.30-0.65)$. By contrast, the amphibole $\mathrm{TiO}_{2}$ content decreases from $1.3 \%-3.0 \%$ to $0.9 \%-1.7 \%$ in andesitic and rhyolitic ashes, respectively. Rare actinolite and ferro-edenite were determined in detrital ash beds and are probably epiclastic fragments.

\section{Biotites}

Biotite flakes were dispersed in many ash layers having different glass composition, with some being included in micropumices ( $\mathrm{Pl} .4$ ). In biotites from calc-alkaline ash beds, the ferromagnesian ratio ranges between 0.33 and $0.59 ; \mathrm{TiO}_{2}$ contents range between $1 \%$ and $4 \%$. In biotites from alkaline ash beds, similar ferromagnesian ratios were found, but $\mathrm{TiO}_{2}$ contents are higher $(4 \%-7 \%)$.

\section{Ilmenite and Epidote}

Grains of ilmenite were analyzed in four rhyolite and rhyodacite ash layers (ilmenite $\mathrm{TiO}_{2}=44.3 \%-48.7 \%$ ). Grains of epidote were determined and analyzed in some detrital ash beds having various glass compositions (Table 2).

\section{Miscellaneous Data}

We analyzed the detrital magmatic minerals (except quartz) of the thick sand beds that were recovered at the bottom of Hole 799B, below the pumice flow (Ingle, Suyehiro, von Breymann, et al., 1990) to determine their petrographic origin (Table 2, Samples 9-S). These consist of potassic feldspar in a small range of composition $\left(\mathrm{Or}_{87-99}\right)$, oligoclase to albite plagioclase that is poor in potassium $\left(\mathrm{Ab}_{78-86}\right.$ and $\mathrm{Or}_{1.2-1.6}$ ), and $\mathrm{Fe}$-biotite (ferromagnesian ratio $=0.62$ ).

\section{ACKNOWLEDGMENTS}

We greatly appreciate the technical assistance of Michel Tallet for the microprobe analyses, Simone Casseault for the geochemical 


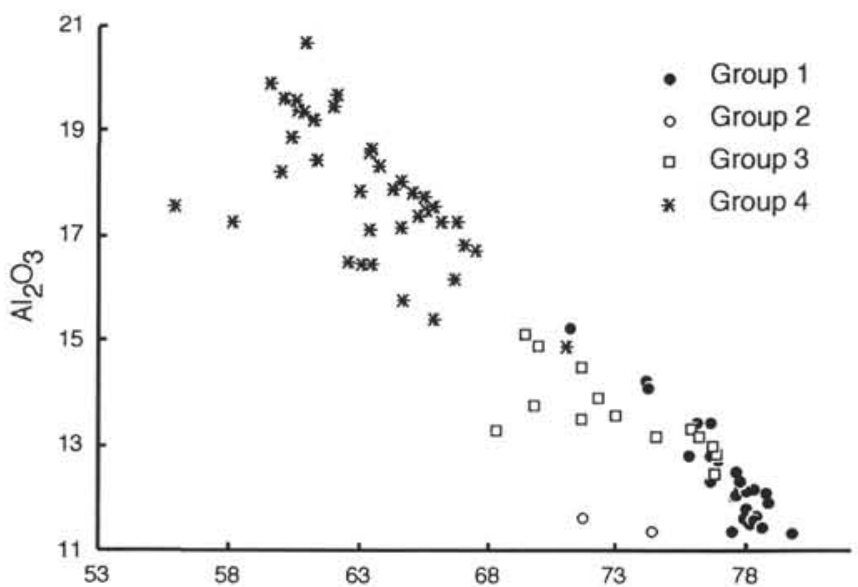

Sites $797-798$

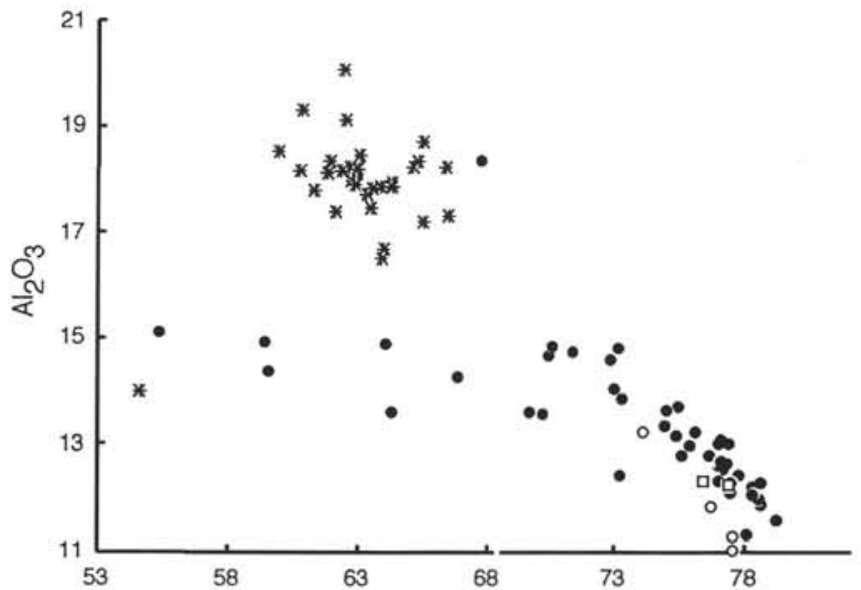

B

Sites 794-796-795

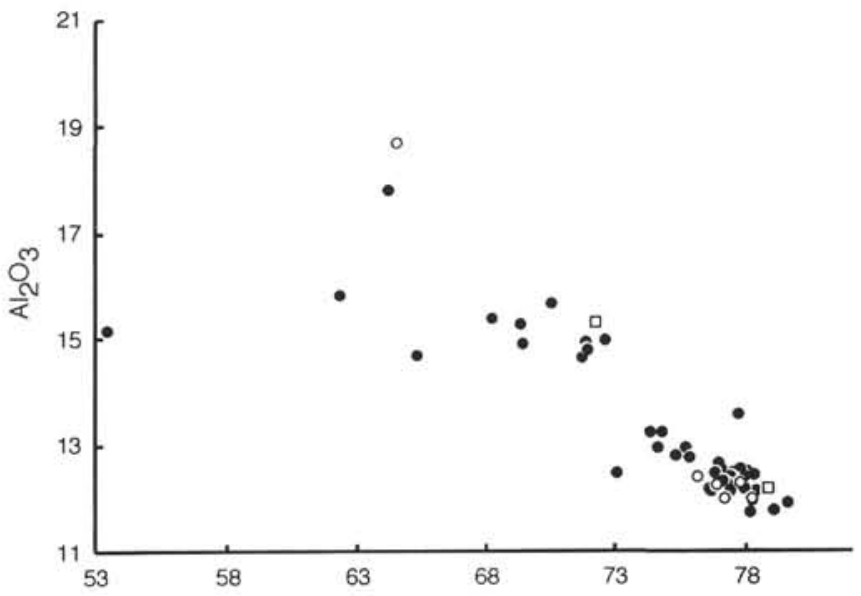

All the Sites

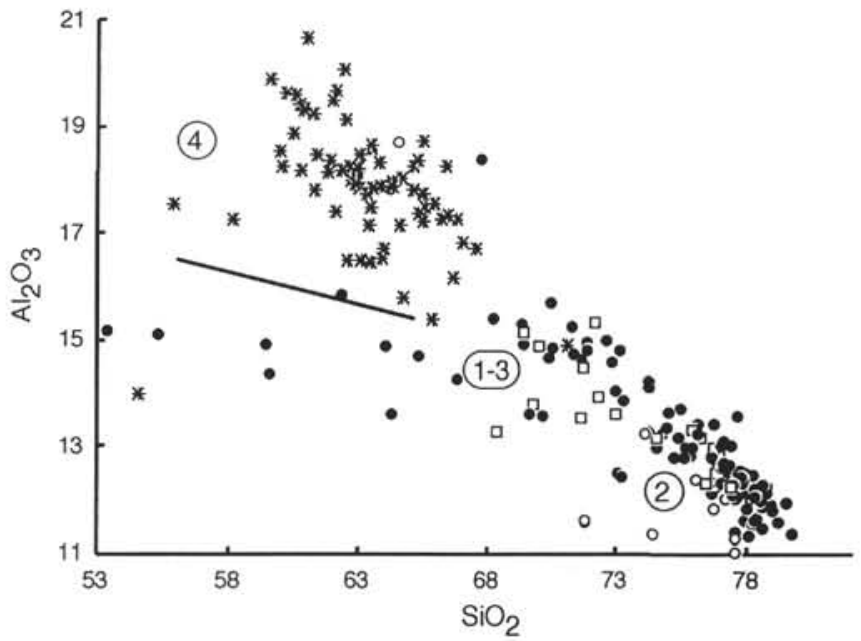

Figure 4. $\mathrm{SiO}_{2}$ vs. oxides (A-L). 1, 2, 3, and $4=$ compositional magmatic groups. $\mathrm{BA}=$ basaltic andesite; $\mathrm{AN}=$ andesite $; \mathrm{DC}=$ dacite $; \mathrm{RD}=$ rhyodacite; $\mathrm{RH}=$ rhyolite; HW = Hawaiite; $\mathrm{PH}=$ phonolite; TP = trachy-phonolite; TR = trachyte; TQ = quartz-trachyte. Boundaries between the low-, medium- and high-K fields after Peccerillo and Taylor (1976).

analyses, and Dominique Panis for the STEM study. This research was supported by a CNRS grant of ODP-France.

\section{REFERENCES}

Evensen, H. M., Hamilton, P. J., and O'Nions, R. K., 1978. Rare Earth abundances in chondritic meteorites. Geochim. Cosmochim. Acta, 42:1199-1212.

Gill, J. B., 1981. Orogenic Andesites and Plate Tectonics: Berlin (Springer-Verlag).

Honnorez, J., 1981. The aging of the oceanic crust at low temperature. In Emiliani, C. (Ed.), The Sea (Vol. 7): The Oceanic Lithosphere: New York (Wiley), 525-587.

Ingle, J. C., Jr., Suyehiro; K., von Breymann, M. T., et al., 1990. Proc. ODP., Init. Repts., 128: College Station, TX (Ocean Drilling Program).

Kastner, M., 1979. Silica polymorphs. In Burns, R. G. (Ed.), Mar. Minerals. Mineral. Soc. Am., Short Course Notes, 99-109.

Kilinc, A., Carmichael, I.S.E., Rivers, M. L., and Sack, R. O., 1983. The ferric-ferrous ratio of natural silicate liquids equilibrated in air. Contrib. Mineral. Petrol., 83:136-140.

Leake, B. E., 1978. Nomenclature of amphiboles. Bull. Mineral., 101:453-467.

Pearce, J. A., and Cann, J. R., 1973. Tectonic setting of basic volcanic rocks using trace element analysis. Earth Planet. Sci. Lett., 19:290-300.

Peccerillo, A., and Taylor, S. R., 1976. Geochemistry of Eocene calc-alkaline rocks from the Kastamonu area, northern Turkey. Contrib. Mineral. Petrol., 58:63-81.
Pouclet, A., 1980. Contribution à la systématique des laves alcalines, les laves du Rift de l'Afrique Centrale (Zaïre-Uganda). Bull. Volcanol., 43:527-540.

Pouclet, A., Cambray, H., Cadet, J.-P., Bourgois, J., and De Wever, P., 1990. Volcanic ash from Leg 112 off Peru. In Suess, E., von Huene, R., et al., Proc. ODP, Sci. Results, 112: College Station, TX (Ocean Drilling Program), 465-480.

Saunders, A. D., and Tarney, J., 1984. Geochemical characteristics of basaltic volcanism within back-arc basins. In Kokelaar, B. P., and Howells, M. F. (Eds.), Marginal Basin Geology. Geol. Soc. London Spec. Publ., 16:59-76.

Tamaki, K., Pisciotto, K., Allan, J., et al., 1990. Proc. ODP, Init. Repts., 127: College Station, TX (Ocean Drilling Program).

Thornton, C. P., and Tuttle, O. F., 1960. Chemistry of igneous rocks. Part I: Differentiation index. Am. J. Sci., 258:664-684.

Whitney, J. A., Dorals, M. J., Stormer, J. C., Jr., Kline, S. W., and Matty, D. J., 1988. Magmatic conditions and development of chemical zonation in the Carpenter Ridge tuff, Central San Juan volcanic field, Colorado. Am. J. Sci., 288-A:16-44.

Date of initial receipt: 24 April 1991

Date of acceptance: 6 January 1992

Ms 127/128B-196 
C

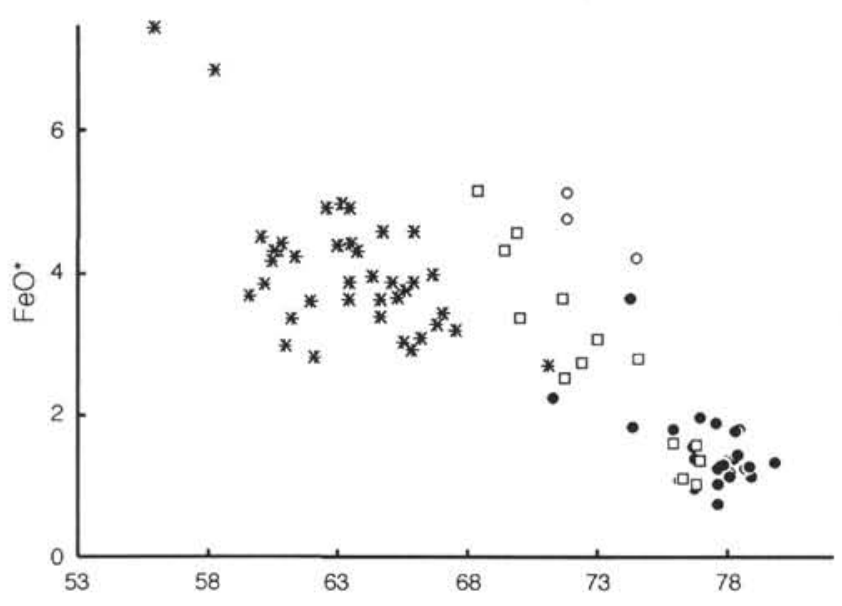

Sites 797-798

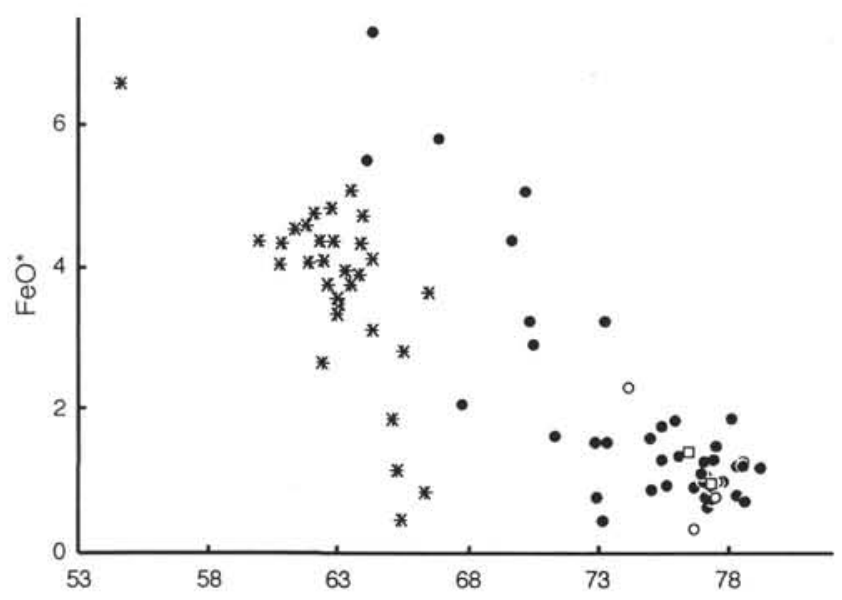

D
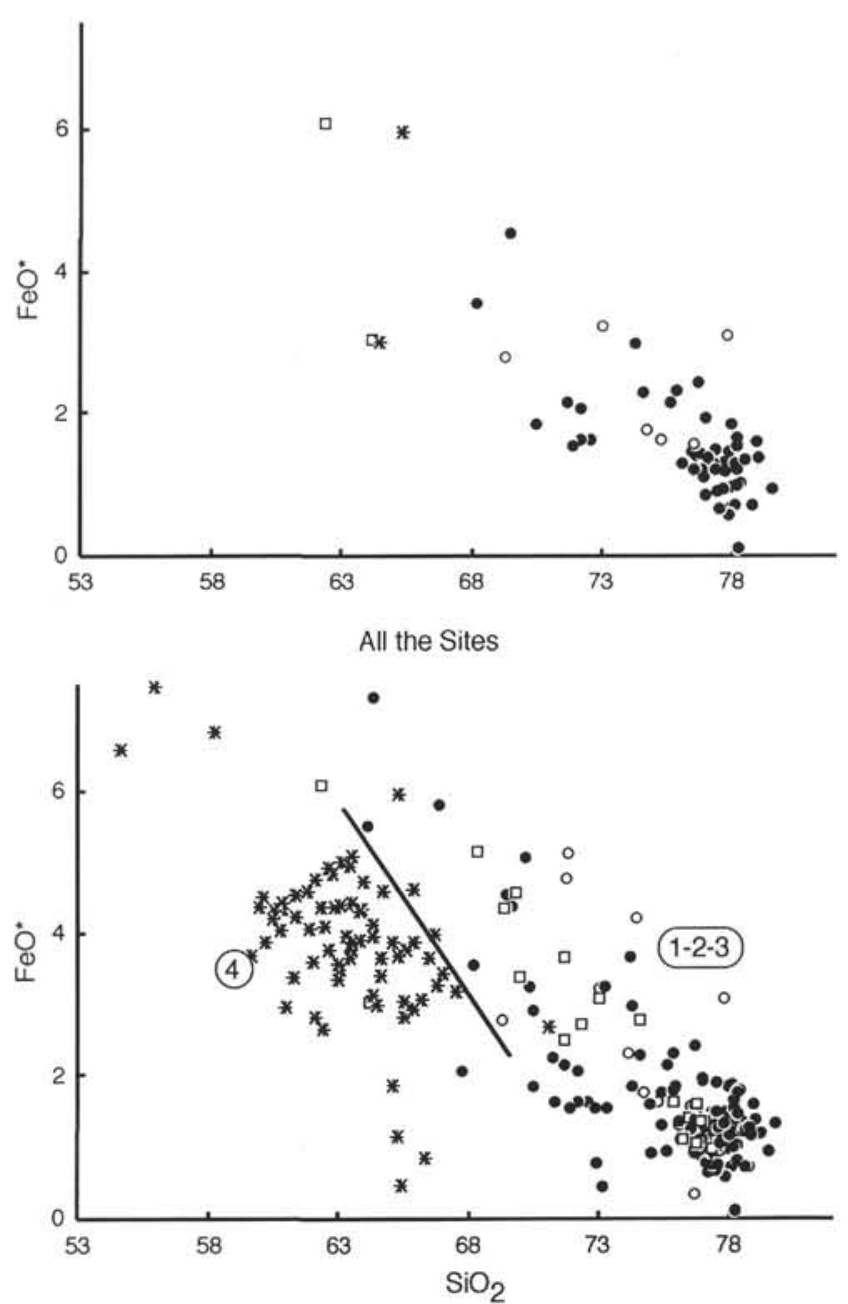

Figure 4 (continued). 
E

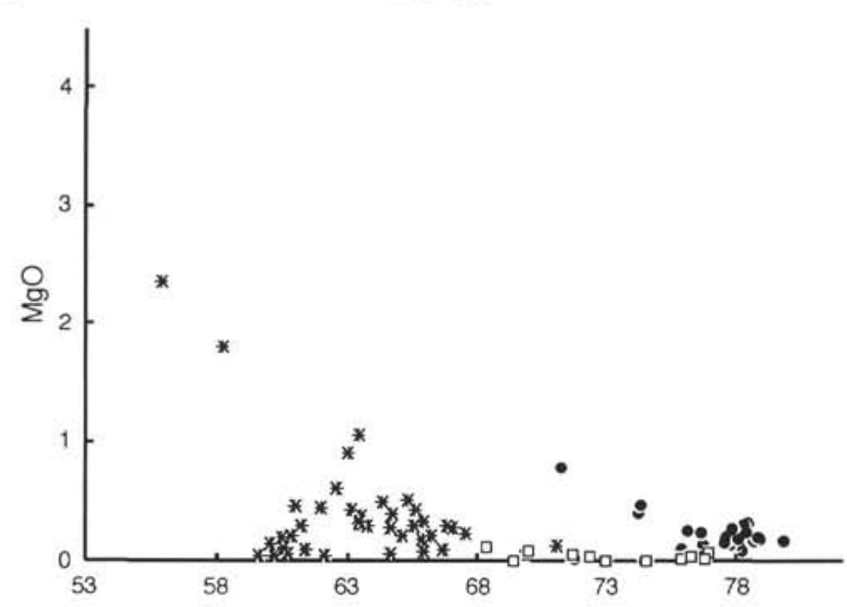

Sites 797-798

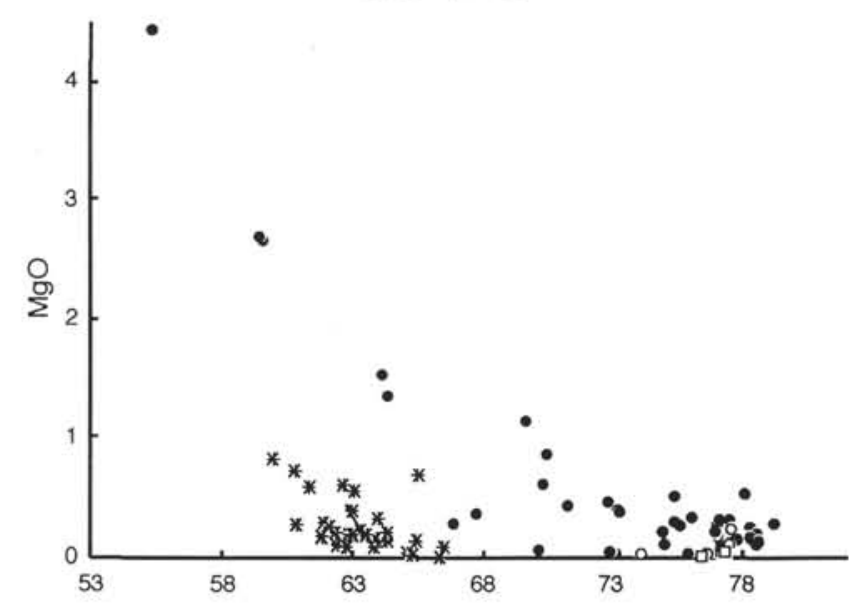

Figure 4 (continued).

\section{$\mathbf{F}$}

Sites 794-796-795

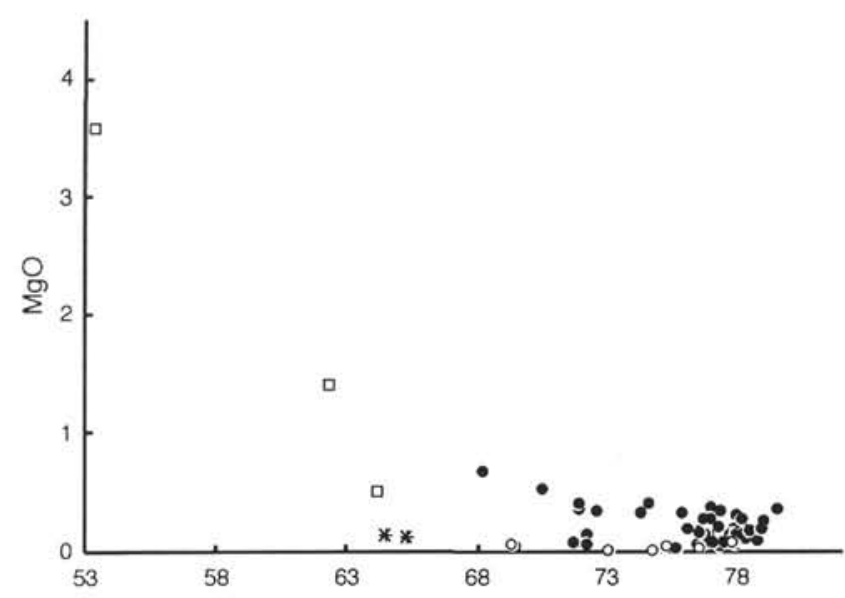

All the Sites

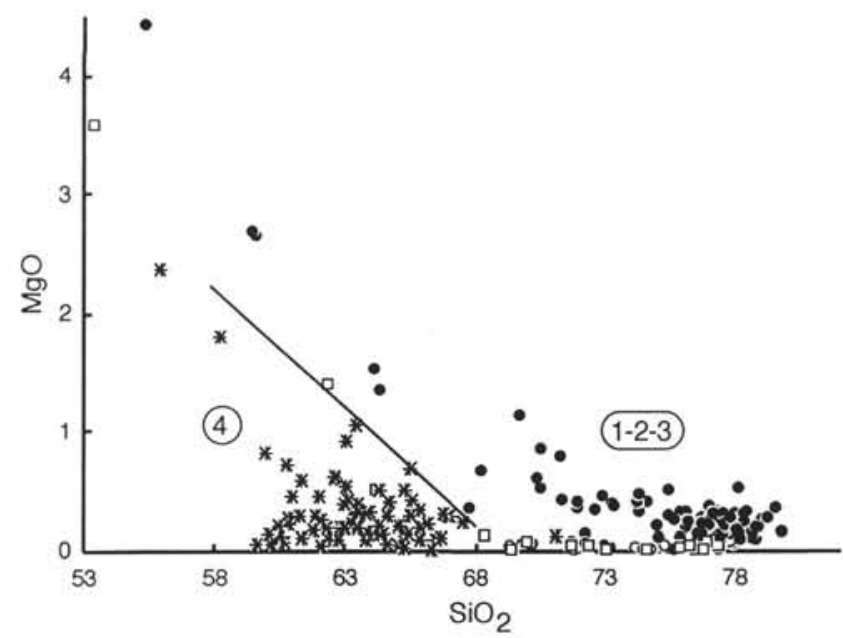


G

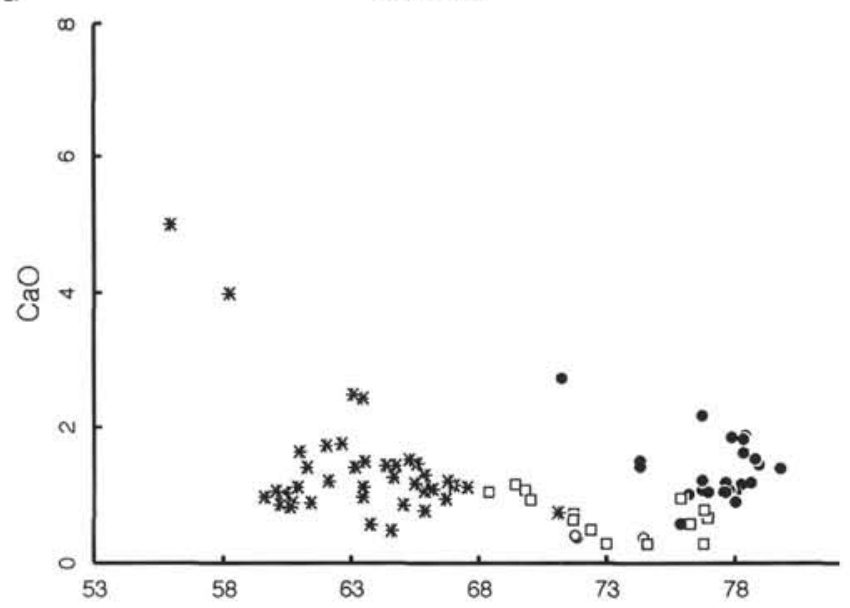

Sites 797-798

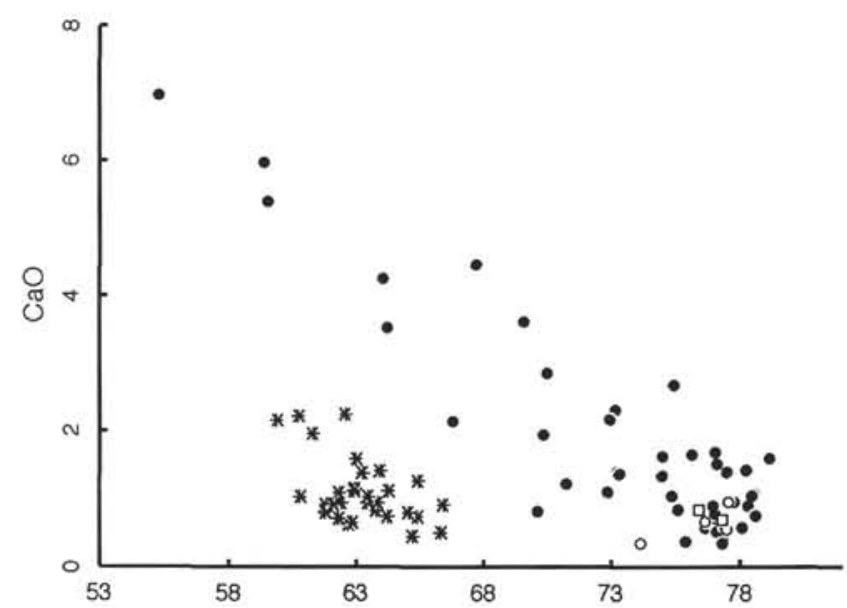

H

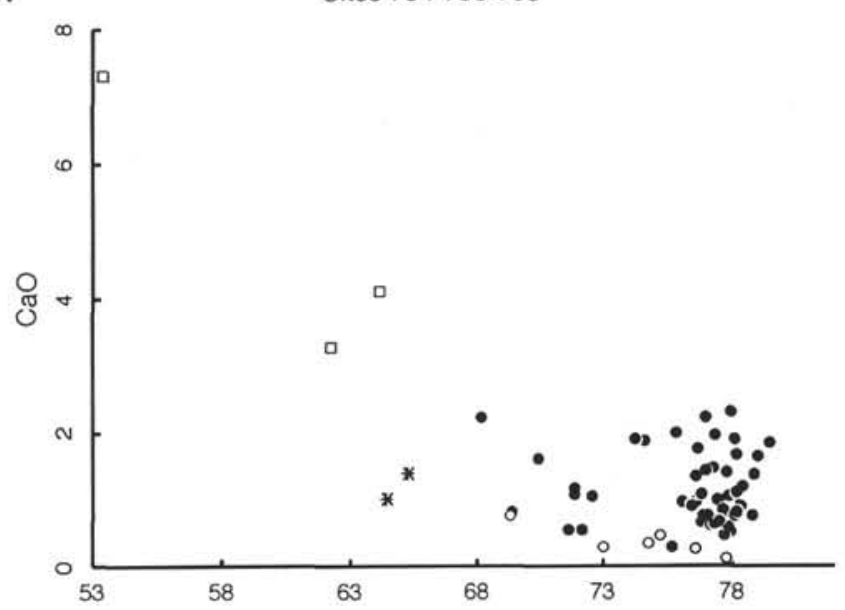

All the Sites

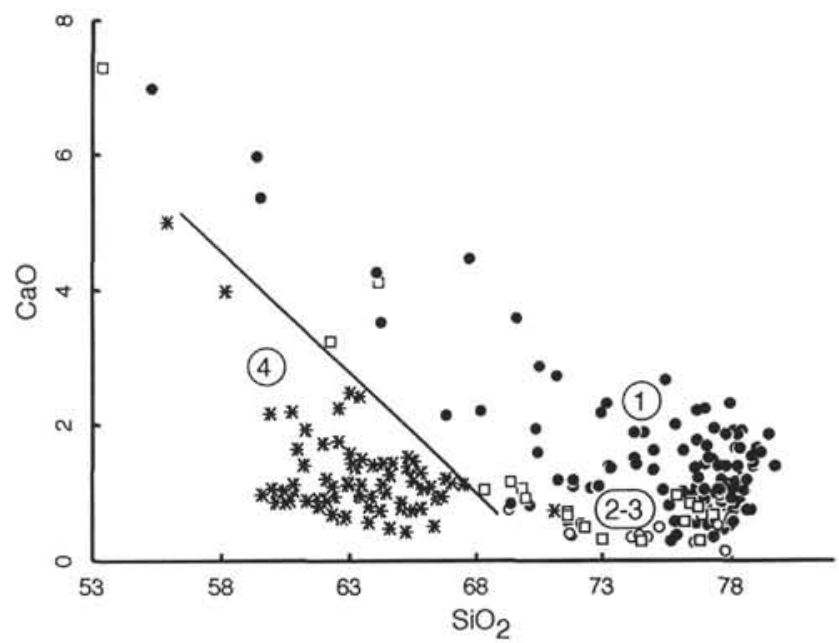

Figure 4 (continued). 
Site 799

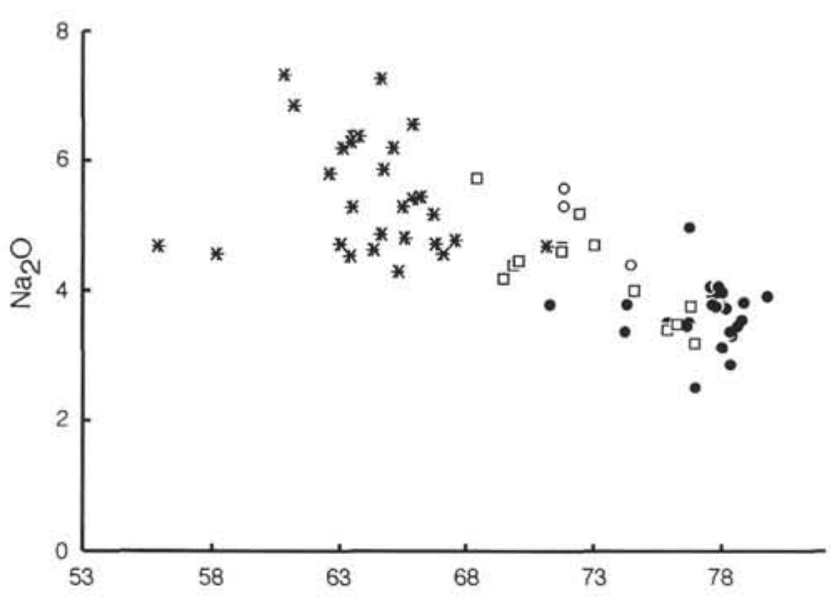

Sites 797-798

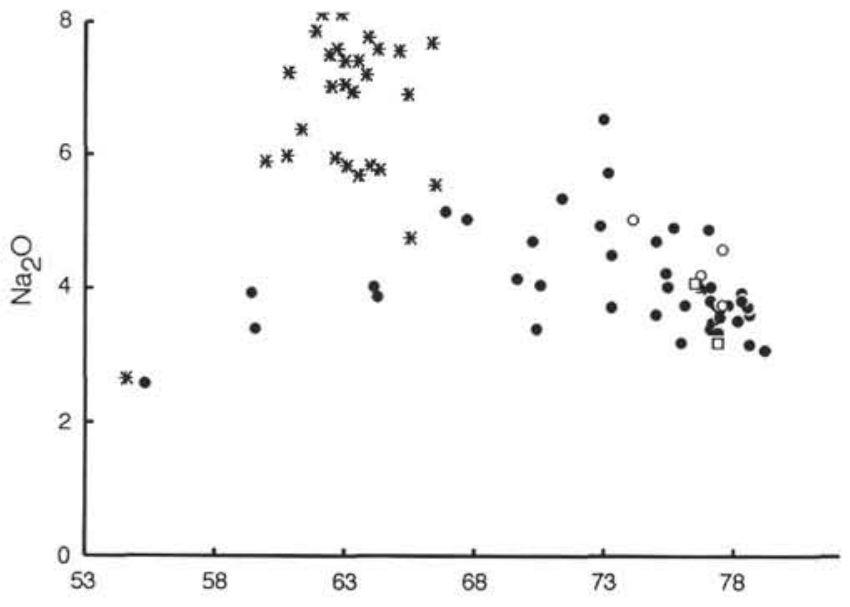

J
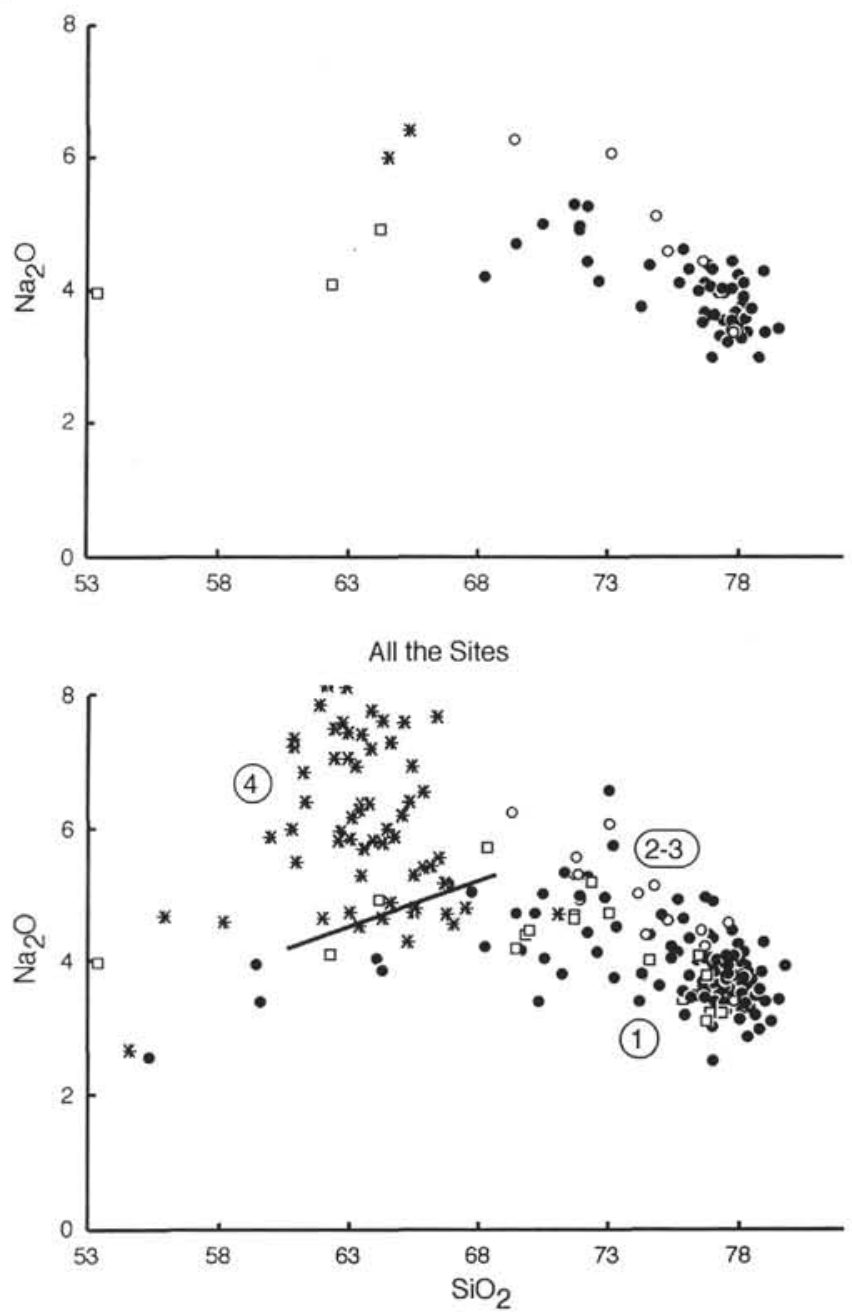

Figure 4 (continued). 
K

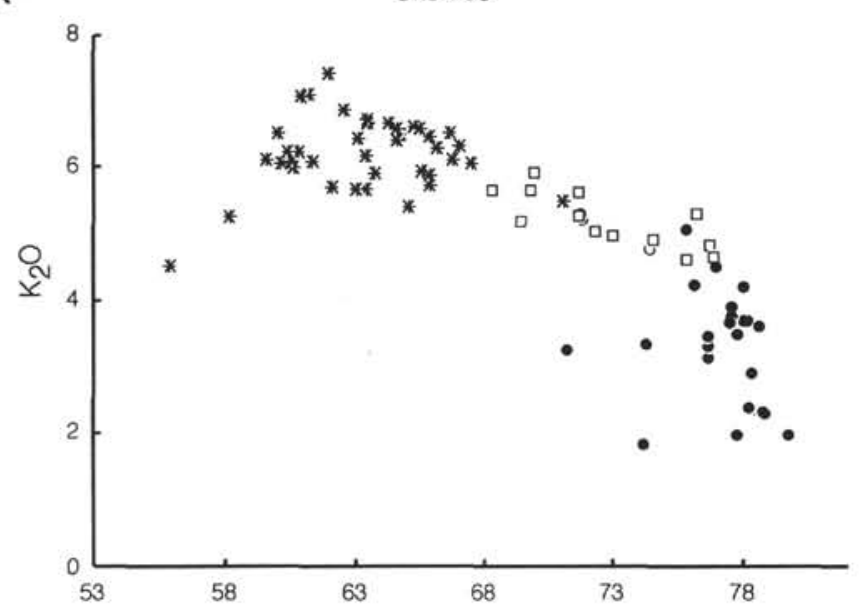

Sites 797-798

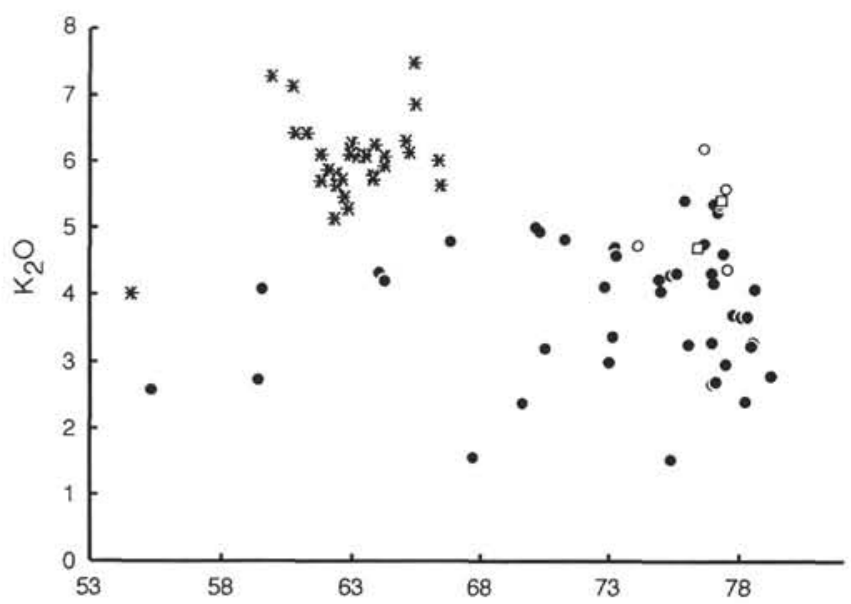

L

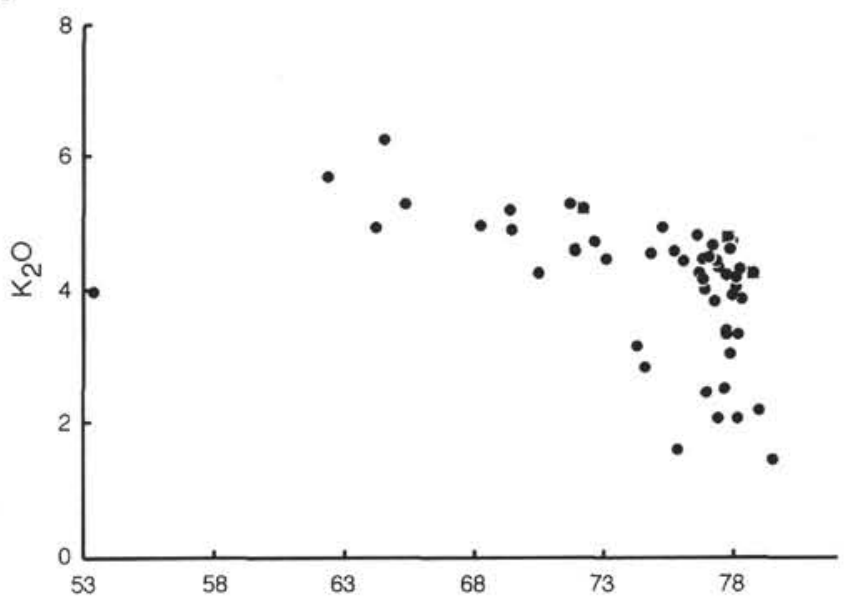

Sites 794-796-795

All the Sites

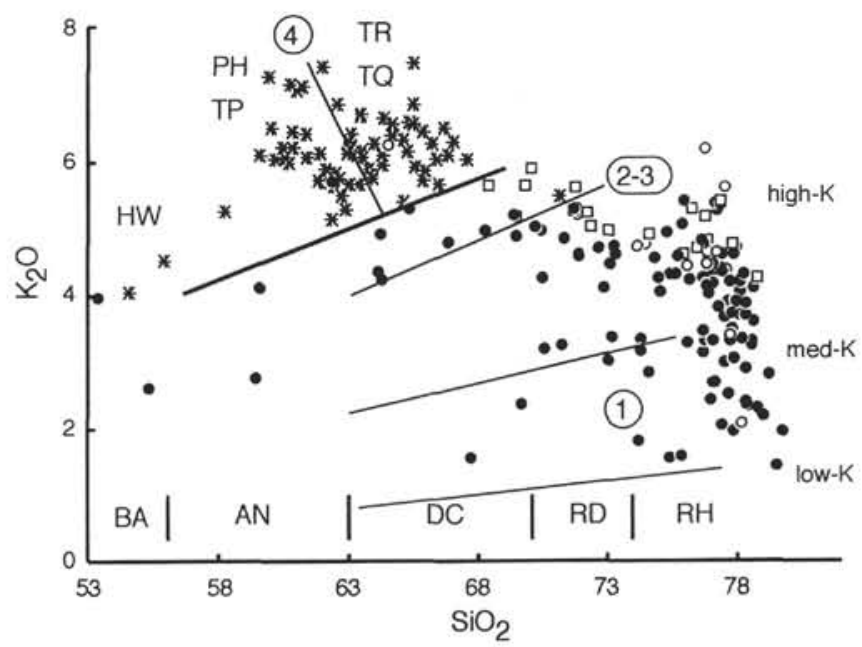

Figure 4 (continued). 
A
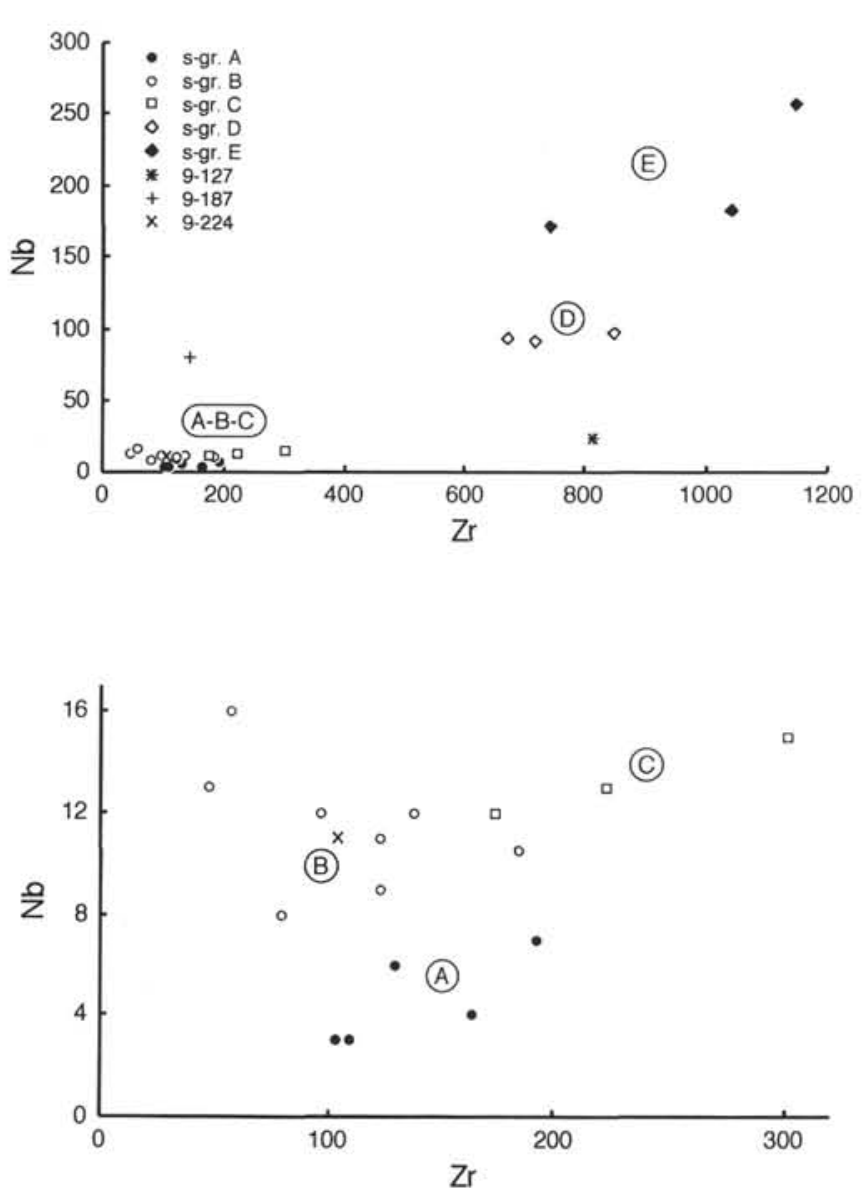

B
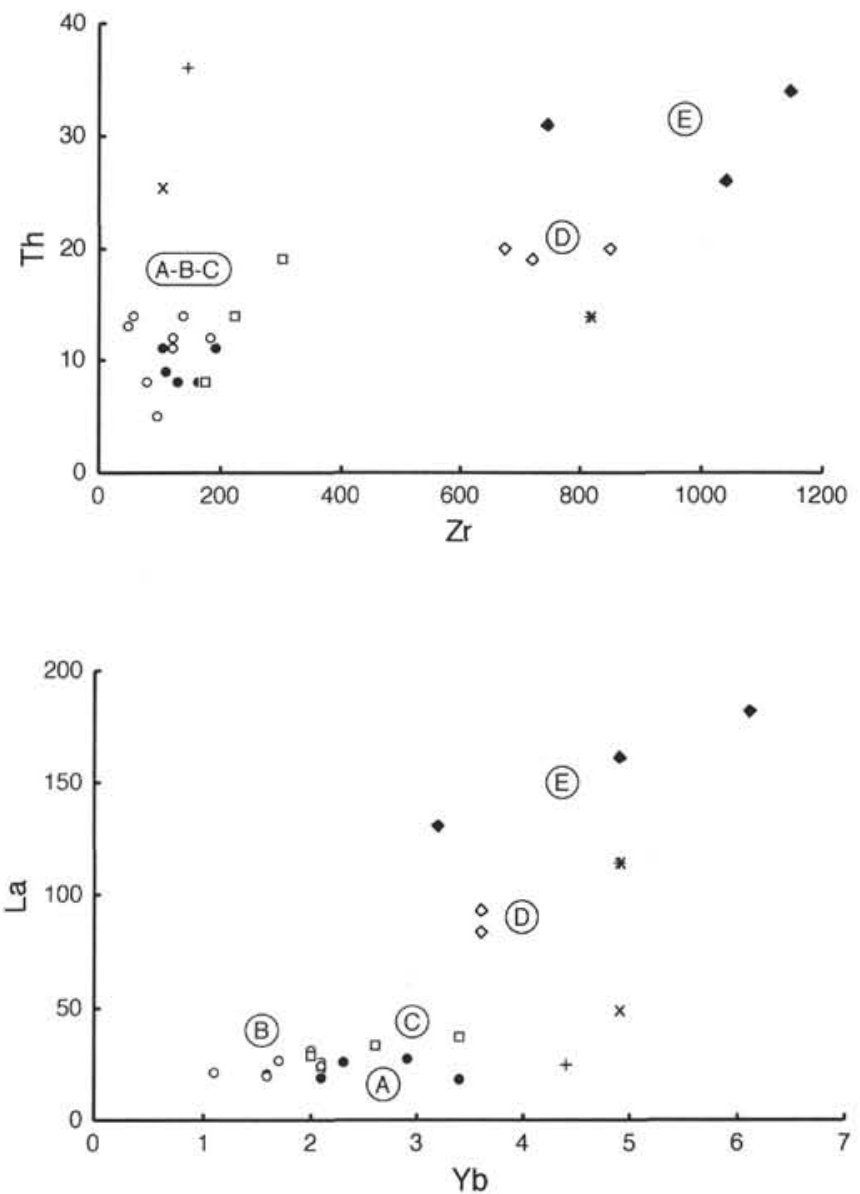

Figure 5. Inter-element correlations of incompatible elements. A. Nb vs. Zr. B. Th vs. Zr and La vs. Yb. A, B, C, and D = compositional magmatic subgroups with in addition the Samples 9-127 = alkaline-rich rhyolite, 9-187 = Th- and Nb-rich rhyolite, and 9-224 = Th-rich rhyolite. 
A

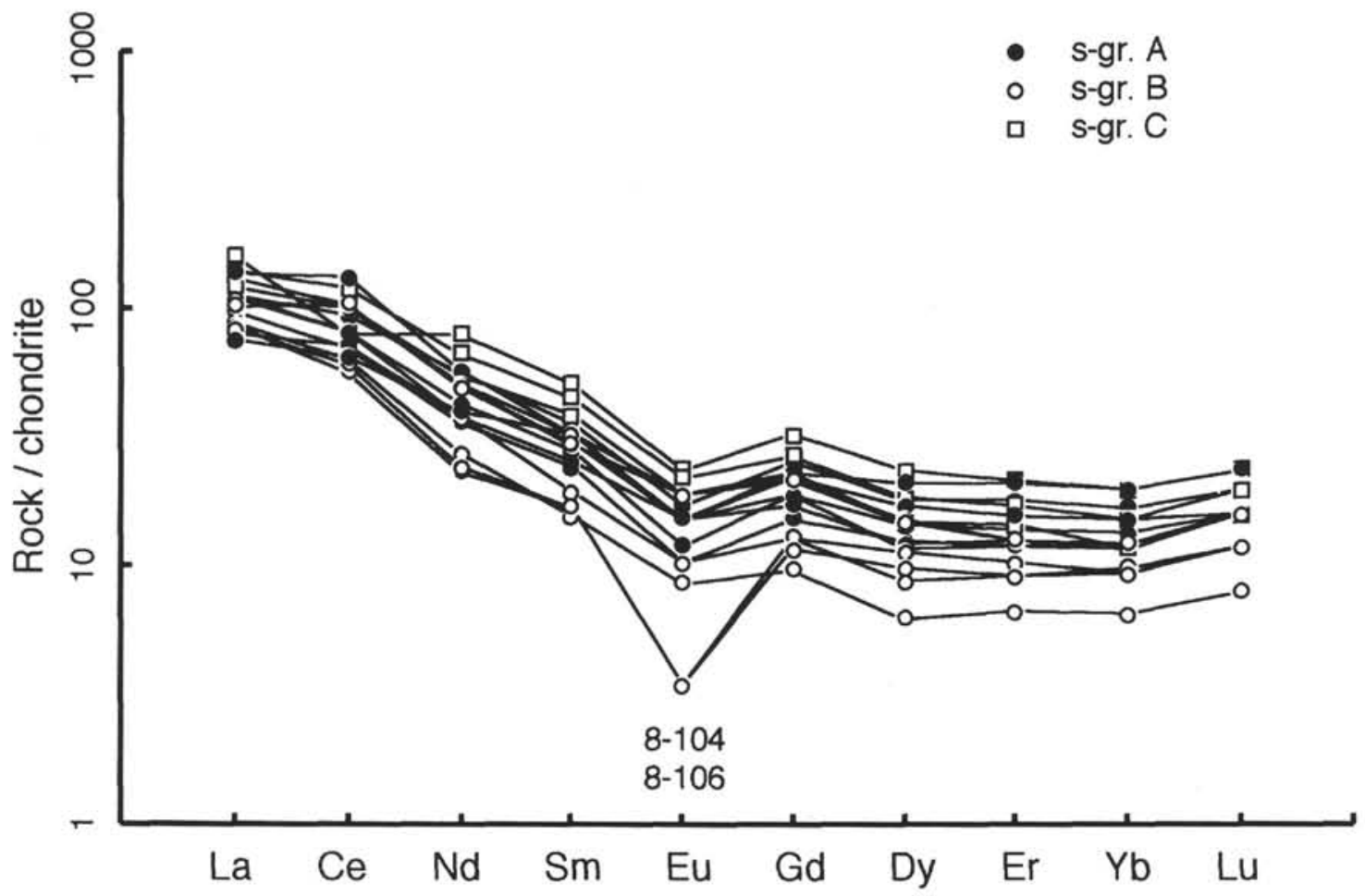

B

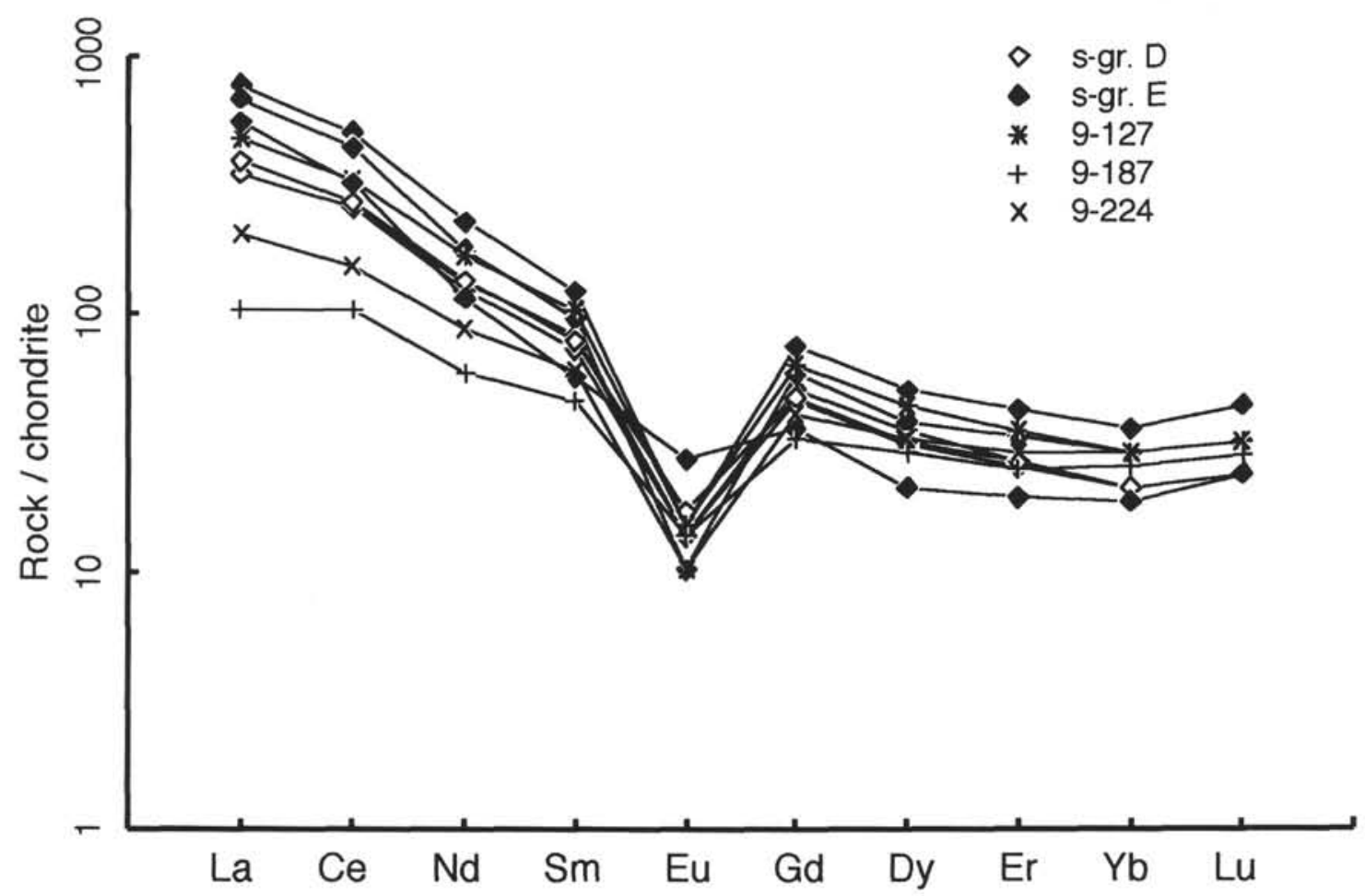

Figure 6. Chondrite-normalized patterns (Evensen et al., 1978). A. Calc-alkaline compositions (Subgroups A, B, and C). B. Alkaline compositions (Subgroups D and E) plus Samples 9-127, 9-187, and 9-224. 


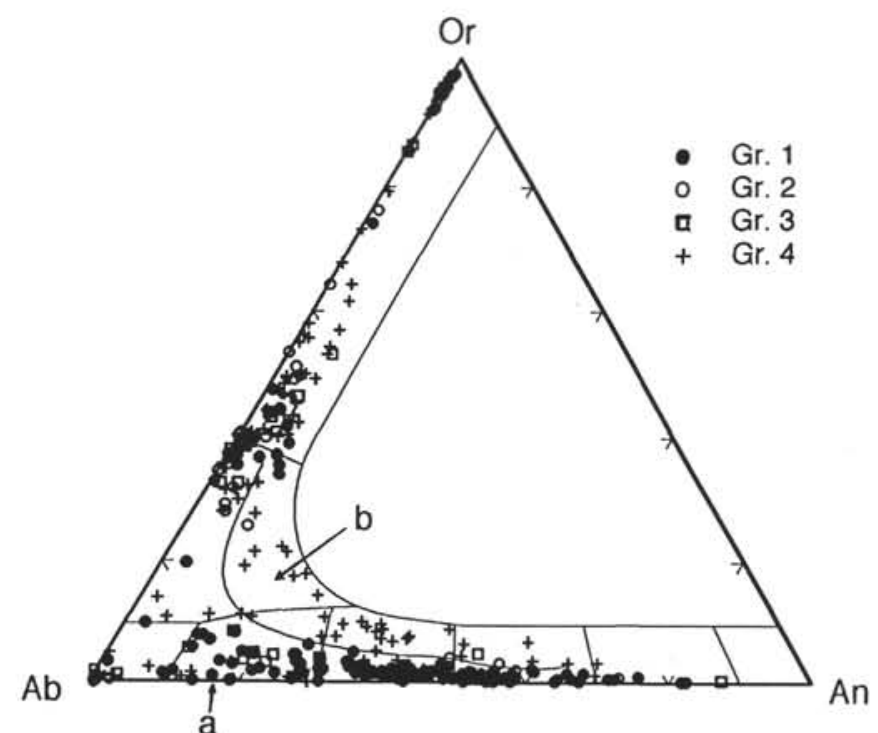

Figure 7. Or-Ab-An diagram of the feldspars. $a=$ Field of the plagioclases of the calc-alkaline magmatic Groups 1, 2, and 3. b = Field of the plagioclases of the alkaline magmatic Group 4.
- Gr. 1, 3

- Gr. 2

$x$ Gr. 4

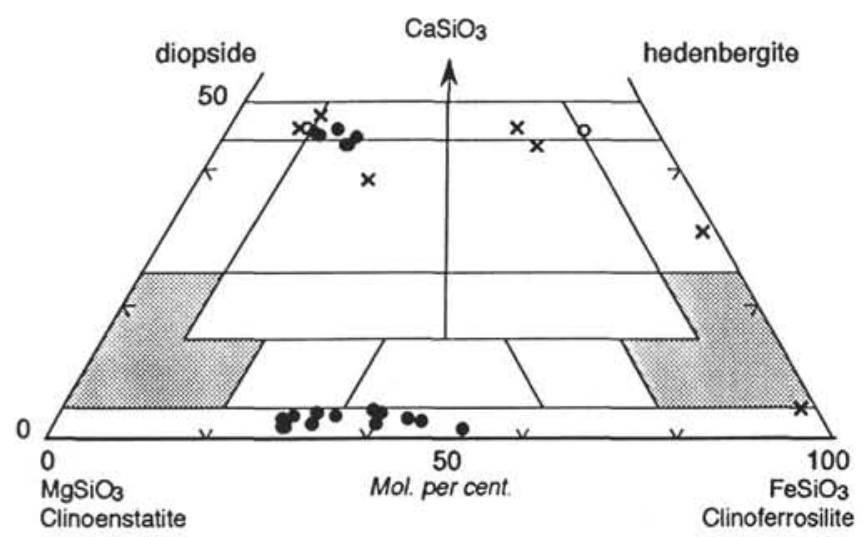

Figure 8. Wo-En-Fs diagram of the pyroxenes $\left(\mathrm{CaSiO}_{3}-\mathrm{MgSiO}_{3}-\mathrm{FeSiO}_{3}\right)$. 

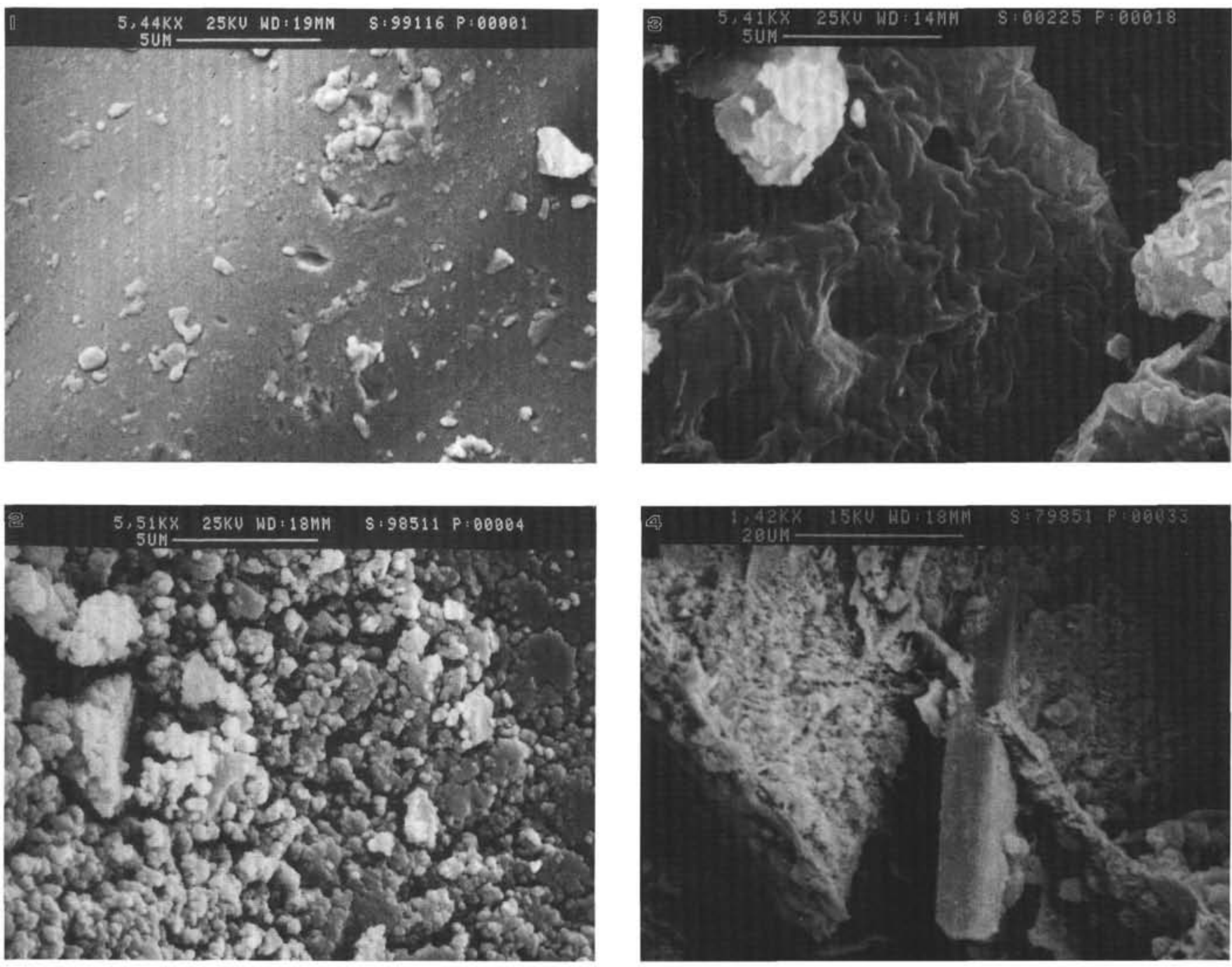

Plate 1. Increasing dissolution of volcanic glass. 1. Scattered small pits (Sample 128-799A-11H-6, 71-72 cm). 2. Strongly pitted glass surface (Sample 128-798B-51X-1, 140-141 cm). 3. Glass dissolution of micropumice (Sample 128-799B-58R-2, 74-77 cm). 4. Lath of feldspar weathered out of glass matrix (Sample 128-798B-51X-1, 140-141 cm). 

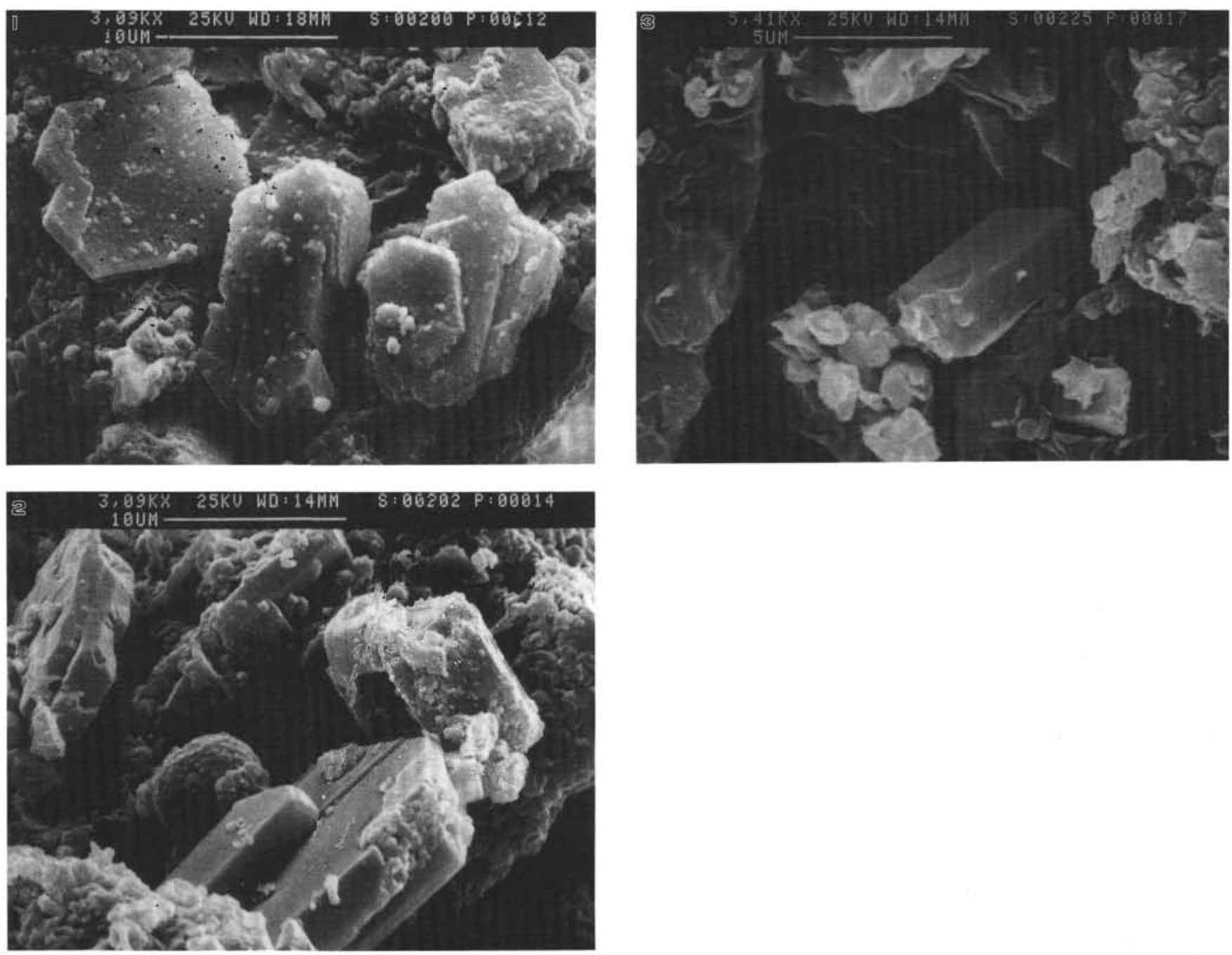

Plate 2. Authigenic feldspar and zeolite. 1. Potassic feldspars (Sample 128-799B-15R-2, 81-83 cm). 2. Potassic feldspars (Sample 128-799B-15R-4, 95-96 $\mathrm{cm}$ ). 3. Clinoptilolite (Sample 128-799B-58R-2, 74-77 cm). 


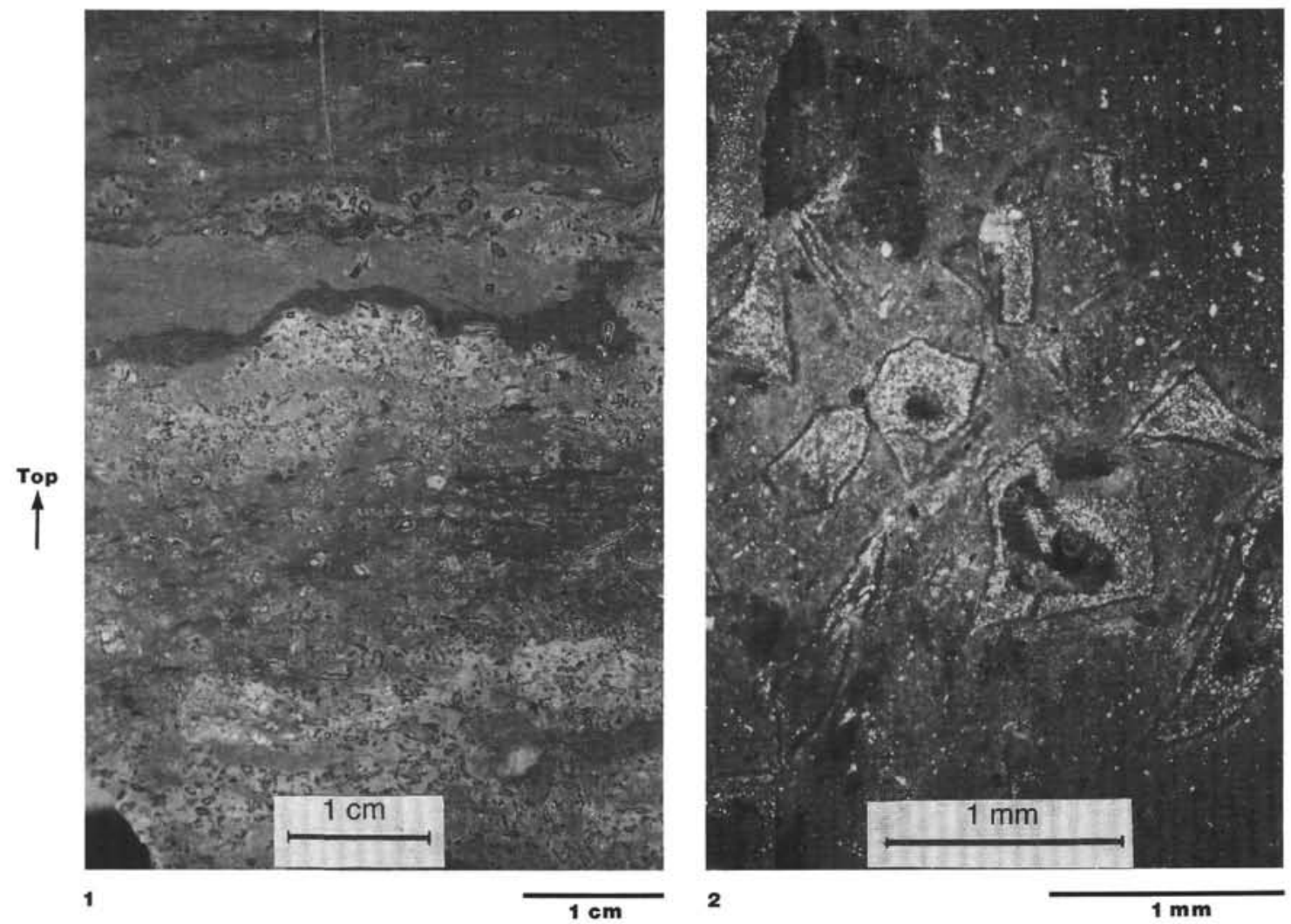

Plate 3. Hyaloclastite layer (interval 128-794D-10R-1 at 142-148 cm). 1. Close-up. 2. Thin section: palagonitized blocky shards. 

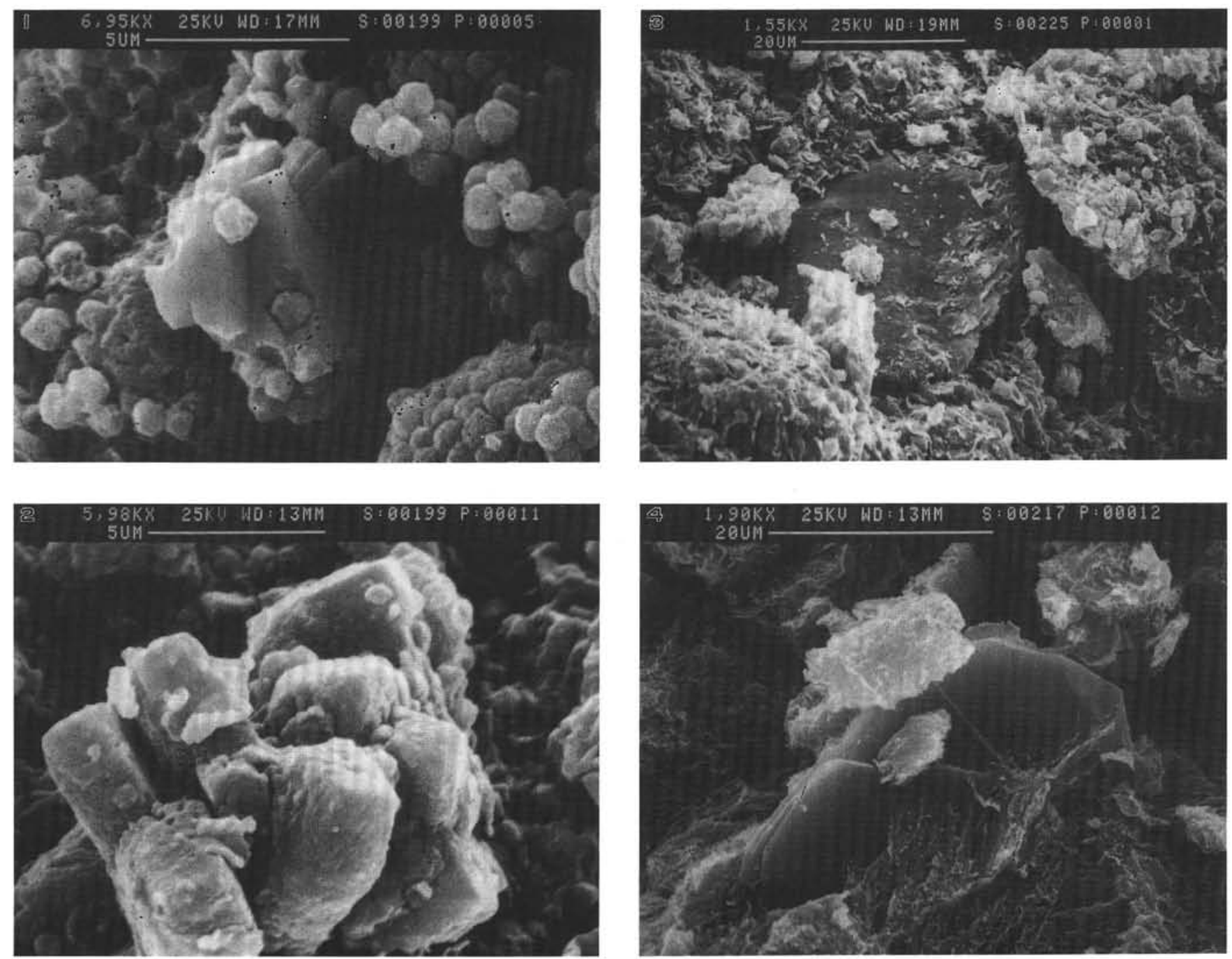

Plate 4. 1, 2. Authigenic barite and pyrite, ash layer 9-199 (Sample 128-799B-14R-2, 32-34 cm). 3, 4. Magmatic minerals; (3) alkaline feldspar in the pumic flow 9-224 (Section 128-799B-58R-2 at 74-77 cm); (4) biotite in ash layer 9-217 (Sample 128-799B-46R-3, 148-150 cm). 

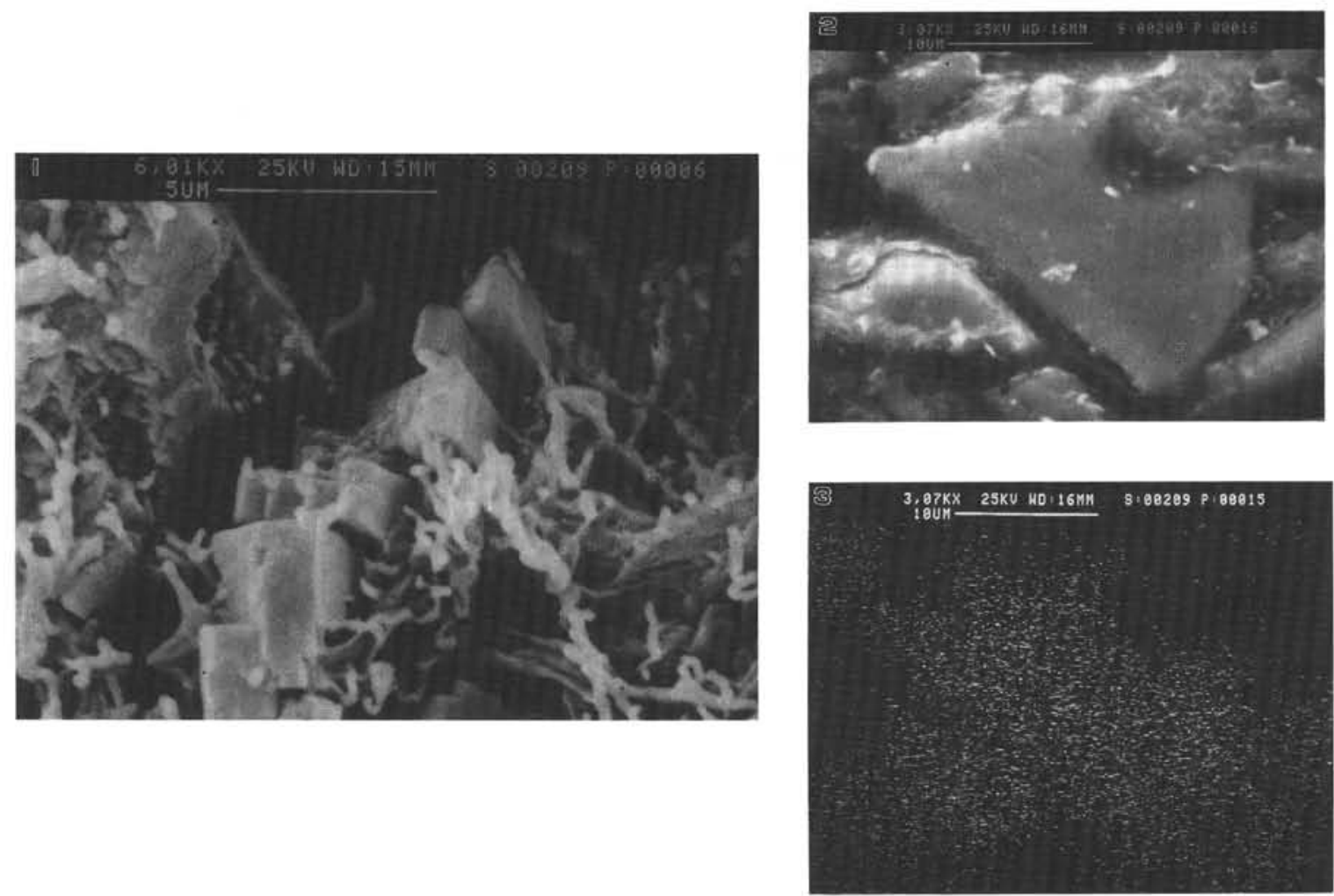

Plate 5. Authigenic harmotome in ash layer 9-209 (Section 128-799B-27R-5 at 47-51 cm). 1. Harmotome crystals growing in glass. 2, 3. Glass shard, X-ray distribution pattern of $\mathrm{Ba}$. 